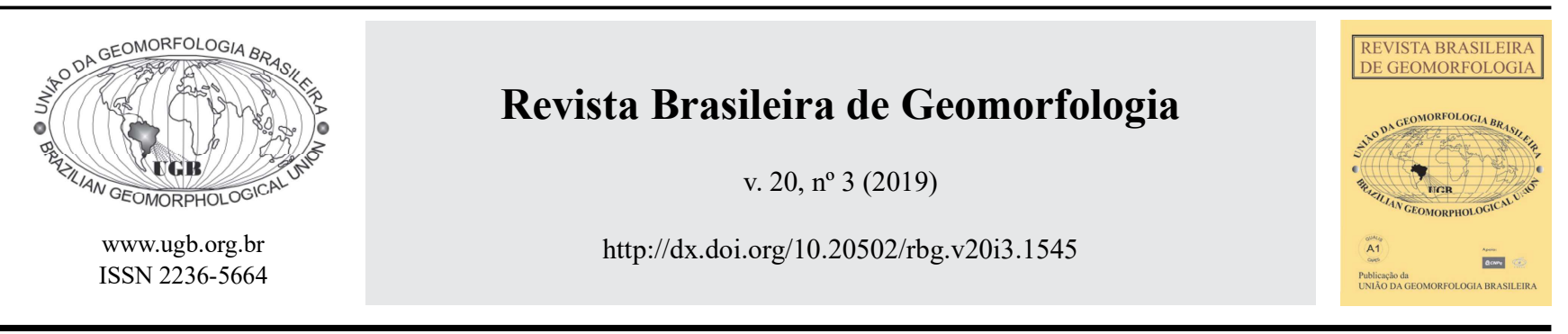

\title{
GEOMORFOLOGIA FLUVIAL DO BAIXO RIBEIRA DE IGUAPE, SÃO PAULO, BRASIL
}

\section{FLUVIAL GEOMORPHOLOGY OF THE LOWER RIBEIRA DE IGUAPE, SÃO PAULO, BRAZIL}

\author{
Yuri Veneziani \\ Departamento de Geografia, Universidade de São Paulo \\ Av. Prof. Lineu Prestes, 338, São Paulo, São Paulo. CEP: 05508-000. Brasil \\ ORCID: 0000-0002-7734-5344 \\ E-mail:yuri.veneziani@usp.br \\ Cleide Rodrigues \\ Departamento de Geografia, Universidade de São Paulo \\ Av. Prof. Lineu Prestes, 338, São Paulo, São Paulo. CEP: 05508-000. Brasil \\ ORCID: 0000-0003-4481-7445 \\ E-mail: cleidrig@usp.br \\ Juliana da Costa Mantovani \\ Departamento de Geografia, Universidade de São Paulo \\ Av. Prof. Lineu Prestes, 338, São Paulo, São Paulo. CEP: 05508-000. Brasil \\ ORCID: 0000-0001-7901-164X \\ E-mail: juliana.mantovani@usp.br
}

\section{Informações sobre o Artigo}

Recebido (Received):

04/01/2019

Aceito (Accepted):

$12 / 06 / 2019$

\section{Palavras-chave:}

Inundação; Planície Meândrica; Hidrogeomorfologia; Mapeamento Geomorfológico; Graben de Sete Barras; Ribeira de Iguape.

\section{Keywords:}

Flood; Meandric Floodplain, Hidrogeomorphology; Geomorphological Mapping; Sete Barras Graben; Ribeira de Iguape River Basin.

\section{Resumo:}

As enchentes decorrentes de processos de inundação são um dos mais graves riscos sociais da atualidade. No Estado de São Paulo, uma das áreas mais suscetíveis é o médio e baixo terços do Vale do Ribeira, onde recorrentes inundações têm levado a graves problemas socioeconômicos. A abordagem geomorfológica, por meio da cartografia geomorfológica, permite indicar fatores do sistema físico que influenciam nas suscetibilidades dos ambientes, avançando na identificação de processos hidrodinâmicos e realização de interpretações morfogenéticas. Este estudo objetivou a compreensão da geomorfologia fluvial da planície meândrica do baixo Ribeira de Iguape, interpretando tendências hidromorfodinâmicas relativas aos processos inundação e apontando aspectos da morfogênese regional. A investigação apoiou-se na elaboração de mapeamento geomorfológico em 1:50.000, com fotointerpretação analógica a partir de estereoscópicos e restituição em SIG; e com campanhas de campo para validação de limites espaciais e levantamento de materiais amostrais. Os resultados indicaram variedade de formas e materiais de canal, planície e terraço no sistema meândrico do baixo Ribeira de Iguape e de paleoambientes fluviais, permitindo a divisão do trecho estudado em duas partes com características geomorfológicas distintas. A distribuição das 
formas e seus arranjos demonstraram controle estrutural da evolução do Graben de Sete Barras na definição de distintos índices de sinuosidade entre as partes de montante e jusante, acompanhadas da alteração do padrão de forma das seções transversais, concentração de barras laterais e ilhas. Há interferências de tal controle na formação e manutenção dos terraços altos no trecho. No que se refere à morfodinâmica, a variabilidade de formas implica distintas tendências de processos hidrodinâmicos. À montante, além de terraços, ocorrem mais de um nível de planície e vastas backswamps sugerindo a predominância de mecanismos de inundação na elaboração da planície. À jusante, além da vasta planície de inundação, a presença de meandros abandonados, cordões e barras laterais permitem afirmar que são significativos os processos de migração lateral. O mapeamento geomorfológico viabilizou o apontamento de tendências espaciais e temporais relativas às inundações nos distintos compartimentos, para os quais graus de suscetibilidades podem ser atribuídos. A variabilidade de formas revela que os processos hidráulicos são descontínuos espacial e temporalmente na planície, impossibilitando, por exemplo, o estabelecimento de valores únicos de cota-vazão para extremos fluviais. A compreensão da suscetibilidade espacial às inundações e sua contribuição à gestão de risco devem considerar aspectos relativos à conectividade dos fluxos na planície fluvial.

\begin{abstract}
:
Flooding is one of the most important worldwide hazard. In the state of São Paulo, one of the most vulnerable areas is the middle and lower Ribeira Valley, where persistent floods have led to serious social and economic losses. The geomorphological approach, through geomorphological mapping, allows to indicate factors of the physical system that influence the susceptibility of the environments, regarding to the spatial and temporal tendencies of the floods, improving the identification of hydrodynamic processes and morphogenetic assessment. This study aimed to understand the fluvial geomorphology of the meandric floodplain of the lower Ribeira de Iguape, interpreting hydromorphodynamic trends related to flooding processes and pointing to aspects of regional morphogenesis. The investigation proceeded over geomorphological mapping in 1:50,000, involving office work with photointerpretation and restitution in GIS and fieldwork for spatial boundaries validation and analysis of sample materials. The results indicated a wide variety of forms and correlative materials of channel, floodplain and terraces in the studied site and its fluvial paleoenvironments, allowing the division of the reach in two halves with different geomorphological characteristics. Regarding to morphogenesis, the distribution of the forms and their arrangements demonstrated the structural control of the evolution of the Graben of Sete Barras in the definition of different sinuosity index between the upstream and downstream halves, also expressed in the change of the cross sections forms, concentration of sandbars and fluvial islands. There is potential disruption of such control in the production and resilience of the high terraces surfaces. Concerning to morphodynamics, the variability of morphological systems implies different tendencies of hydrodynamic processes. Upstream, besides terraces (that denounce the fluvial incision), levels of floodplains and backswamps prevail in this part, which suggests the predominance of flooding mechanisms in the floodplain formation; while downstream, the presence of paleomeanders and point bars allow us to consider lateral migration as dominant fluvial processes. The geomorphological mapping enabled us to the identification of the spatial and temporal trends related to different systems flooding. The variability of forms revealed spatialtemporal discontinuous relationship on hydraulics variables, making it impossible to establish single values of rating-curves for fluvial extremes and geomorphological systems. The understanding of vulnerability to flooding and its contribution to risk management should include considerations about hydraulic-sedimentological connectivity.
\end{abstract}

\section{Introdução}

As enchentes decorrentes de processos de inundação fazem parte de um dos mais graves e frequentes problemas sociais da atualidade, com um aumento no número de eventos nos últimos 50 anos em todo mundo
(CRED; GUHA-SAPIR, 2018). No Brasil, caracteriza-se como desastre natural ${ }^{1}$ responsável pelo maior número de vítimas e perdas sociais e econômicas, com mais de 1.380.000 pessoas afetadas apenas em 2013 (CENAD, 2014). No Estado de São Paulo, a região do médio e

\footnotetext{
${ }^{1}$ Impacto do ambiente natural (de processos a ele relacionados) sobre o sistema socioeconômico. Súbito desequilíbrio do balanço entre as forças relativas ao sistema natural e as forças contra-atuantes do sistema social (ALCÁNTARA-AYALA, 2002).
} 
baixo vale do rio Ribeira de Iguape é, historicamente, a de maior suscetibilidade às inundações (RODRIGUES, 2015) sofrendo sucessivas perdas socioeconômicas ao longo das últimas décadas, destacando-se os recentes eventos de 1997 e 2011 (AMARAL, 2014). Esta suscetibilidade (ALCÁNTARA-AYALA, 2002; VEYRET, 2015) é explicada tanto por fatores de ordem natural, decorrentes da configuração geomorfológica da bacia hidrográfica (SANTANA, 2008), quanto por fatores de ordem social, visto que abrange municípios com menor desenvolvimento social e econômico do Estado de São Paulo (SEADE, 2013). Esta suscetibilidade é marcante entre os municípios de Eldorado e Sete Barras (Setor ESB), onde os impactos dos eventos de inundações extremas expuseram a emergência de se realizar o monitoramento e gestão do risco hidrológico na região.

A abordagem geomorfológica viabiliza a compreensão de fatores do sistema físico que influenciam na suscetibilidade de tais sistemas, que pode ser definida como a probabilidade de ocorrência de um dado evento geomorfológico (BRUNSDEN, 1996), caracterizado pela sua capacidade formativa, e pelas suas expressões temporais (magnitude-frequência) e espaciais. A análise da morfologia fluvial e seus materiais, apoiadas na cartografia geomorfológica, permite indicar tendências de processos hidrodinâmicos atuais e pretéritos, e realizar interpretações morfogenéticas (HART, 1986). Reconhecer as formas é fundamental para entender a morfodinâmica fluvial (HART, 1986; RODRIGUES, 1997; TRICART, 1965).

A faixa atlântica do sul e sudeste brasileiros, onde está o vale do Ribeira de Iguape, é marcada pelo Rift Continental do Sudeste Brasileiro (RICCOMINI, 1989) que integra o cinturão Orogenético do Atlântico. Esta macroestrutura foi responsável pela constituição de agentes endógenos que caracterizam a região (intrusões alcalinas, vales estruturais, morrarias, maciços montanhosos, escarpas de falhas, blocos abatidos) dentre os quais, grabens e hemi-grabens, onde se desenvolveram as Bacias Sedimentares Cenozóicas (ROSS; MOROZ, 1997). O terço inferior do vale do Ribeira estruturou-se sobre o Graben de Sete Barras (ROSS, 2002), um dos fatores de ordem natural que condiciona a suscetibilidade elevada à inundação, devido à configuração do perfil longitudinal do rio principal e afluentes (SANTANA, 2008).

Entre as décadas de 1970 e 1990 foram realizadas investigações a respeito das superfícies de aplainamento localizadas nesta bacia, nas quais enfatizaram-se os paleopavimentos rudáceos e suas possíveis gêneses correlativas aos das bacias Sedimentares de São Paulo, Taubaté e Volta Redonda (AB'SABER, AZIZ NACIB, 1969; BERTUCCI et al., 2018; BIGARELLA; MOUSINHO, 1965a;1965b; MELO, MARIO SERGIO DE, 1990; MELO, MÁRIO SÉRGIO DE; FERNANDES; COIMBRA, 1990; MELO, MÁRIO SÉRGIO DE; FERNANDES; COIMBRA; MORAES, 1989). Estes estudos contribuíram para avanços no entendimento dos paleoambientes regionais, porém, em relação ao sistema fluvial meandrante tropical poucos estudos foram efetuados na região. O objetivo deste trabalho foi compreender a variedade, distribuição e arranjo das formas fluviais e materiais da planície fluvial meândrica do baixo Ribeira de Iguape, entre os municípios de Eldorado e Sete Barras, buscando identificar suas tendências hidromorfodinâmicas internas, sobretudo relativas a processos inundação, buscando apontar aspectos que podem ser vinculados à morfogênese do setor.

$\mathrm{O}$ estudo baseou-se em mapeamento geomorfológico de escala 1:50.000, no qual foram identificadas as principais categorias de formas presentes nos subsistemas canal fluvial, planície fluvial e terraço. $\mathrm{O}$ mapeamento foi produzido com fotointerpretação analógica restituída em SIG, e tomou como base dados cartográficos oficiais, além de mapeamentos geomorfológicos e geológicos secundários. A descrição dos materiais foi realizada em campanhas de campo. As descrições morfológicas e dos materiais, que constam nos resultados deste estudo, permitiram a proposição de interpretações morfodinâmicas e morfogenéticas, contidas no item de discussões.

\section{2. Área de estudo}

A bacia hidrográfica do rio Ribeira de Iguape (BHRB) é a maior bacia exorreica do sudeste brasileiro, com extensão total de $470 \mathrm{~km}$, drenando $26.792,37 \mathrm{~km}^{2}$ entre os Estados do Paraná e São Paulo (PANAPANÁ, 2016), incluindo totalmente os municípios de Eldorado e Sete Barras (Figura 1). Os principais rios formadores do Ribeira de Iguape são Ribeirinha e Açunguí, ambos com nascentes acima de $1.000 \mathrm{~m}$ de altitudes, e cujas bacias hidrográficas abrangem mais de $30 \%$ da BHRB. Suas nascentes localizam-se no reverso da Serra de Paranapiacaba, onde se desenvolvem por erosão com capturas fluviais no Planalto do Turvo (ROSS, 2002) (Figura 2). 
Veneziani Y. et al.
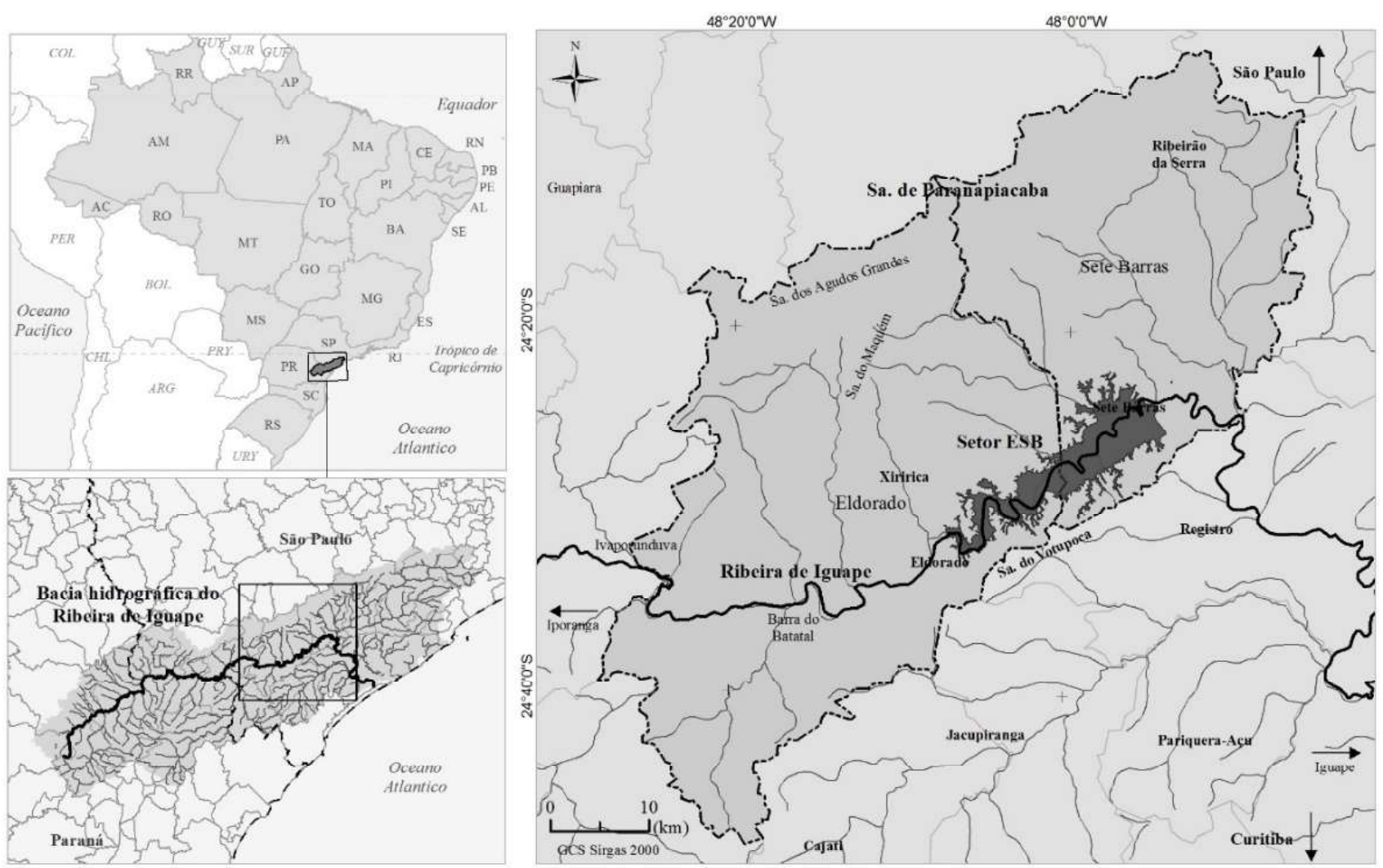

Figura 1 - Localização do setor ESB (Eldorado - Sete Barras).

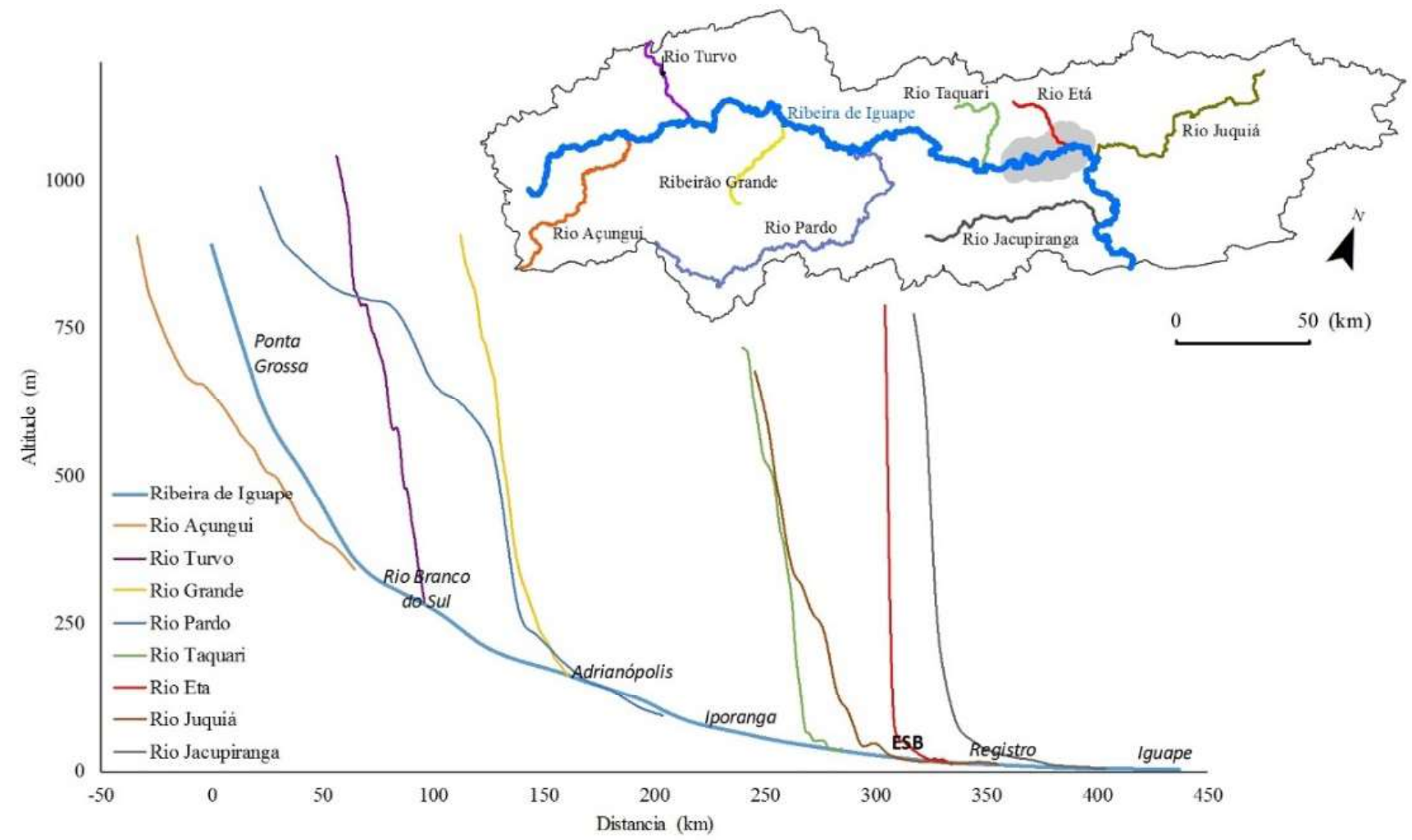

Figura 2 - Perfil longitudinal do Ribeira e principais afluentes (MIRANDA, 2008), SIGRB (2017). 
O clima predominante é tropical úmido com chuvas bem distribuídas e sazonalidade marcada por verão quente e úmido e inverno frio e menos úmido (CEPAGRI, 2015). Localizado no limite da região tropical, os principais controles climáticos sinópticos no setor ESB relacionam-se: (i) à Zona de Convergência Intertropical (ZCIT), que influencia na ação da Zona de Convergência do Atlântico Sul (ZCAS, que determina regime monçônico do sul amazônico ao sudeste do Brasil); e (ii) ao avanço de sistemas frontais que geram longas faixas de instabilidade e precipitação. Regionalmente, durante o verão (dezembro a março) intensificam-se sistemas convectivos locais (TARIFA, 2004), quando concentram mais de $60 \%$ da precipitação anual, com média de $1.800 \mathrm{~mm} / \mathrm{ano}$. O rio Ribeira de Iguape é o único rio de grande porte do Estado de São Paulo que não possui controles hidráulicos significativos, como represamentos (DAEE, 1999), o que salienta a necessidade de reconhecer-se o funcionamento e regime hidrológicos naturais para indicar tendências de inundações.

Geologicamente, a BHRB está em faixa de dobramentos e metamorfismos regionais Pré-cambrianos (Ciclo Brasiliano) que formaram diques e complexos de falhas e fraturas do Cinturão Orogenético do Atlântico (ALMEIDA, 1974), o qual se expressa pelo alinhamento de espigões, morrarias e distribuição de planícies alveolares (ROSS; MOROZ, 1997). Segundo dados do CPRM (2016), nas cabeceiras da BHRB predominam rochas ígneas (granito-gnaisse-migmatíticas anteriores a 500mi) dobradas e fraturadas que estruturam as Serras de Paranapiacaba e de Juquiá-Guaçu, e planaltos do rio do Turvo e Ibiúna/São Roque, com morrarias de alto grau de dissecação (THEODOROVICZ; THEODOROVICZ, 2007). No terço médio predominam rochas metamórficas, incluindo conjuntos carbonáticos, filitos e micaxistos, e rochas ígneo-metamórficas, como gnaisses graníticos. No terço de jusante, onde está o setor ESB, predominam pacotes sedimentares fluviais na depressão fluvial do baixo Ribeira de Iguape (Graben) e sedimentos marinhos na planície de Cananeia.

O setor ESB é seccionado pelo alinhamento estrutural Guapiara, com diques máficos, perpendicular ao eixo de cisalhamento regional (Figura 3), e o fundo do vale é interpretado como área abatida do Graben de Sete Barras (CPRM, 2013;2014). Trata-se de depressão tectônica alongada (SW-NE) situada entre Sete Barras e Eldorado, de $20 \mathrm{~km}$ de comprimento e $5 \mathrm{~km}$ largura (MELO, MÁRIO SÉRGIO DE; FERNANDES; COIMBRA; RAMOS, 1989), formada por colinas e vales de fundo plano, de fraco entalhamento $(<40 \mathrm{~m})$ e dimensões interfluviais pe- quenas $(<750 \mathrm{~m})$, topos de $\pm 30 \mathrm{~m}$ de altitude e declividades $<20 \%$ (ROSS, 2002). No fundo do vale ocorrem pacotes sedimentares que nesta zona são atribuídos à Formação Pariquera-Açu (AB'SABER, A. N., 1972; BIGARELLA, 2007; BIGARELLA; ANDRADE, 1965; BIGARELLA; MOUSINHO, 1965a) composta de espessos pacotes de cascalhos heterométricos (ROSS; MOROZ, 1997). Esses pacotes são indicativos de falhas normais e inversas (trativas e compressivas) que sugerem formação sintetônica às Bacias de São Paulo, Taubaté, Resende e Volta Redonda (MELO, MÁRIO SÉRGIO DE et al., 1990). MELO, MARIO SERGIO DE (1990) subdivide a Formação Pariquera-Açu em cinco: Formação Sete Barras (Plio-Pleistocênica), Formação Pariquera-Açu propriamente dita (Pleistoceno Superior), depósitos de cascalho em nível topográfico superior de terraços e em nível topográfico intermediário de terraços (Pleistoceno Inferior a médio) e depósitos holocênico (além de colúvios). Os sedimentos Holocênicos correspondem ao sistema hidromorfodinâmico atual e compõem diversos sistemas deposicionais de planície e baixos terraços ( $<10 \mathrm{~m}$ de altura das margens plenas).

\section{Materiais e Metodologia}

A abordagem geomorfológica, por meio da cartografia geomorfológica, permite reconhecer e caracterizar a variedade e espacialidade das formas da planície fluvial meandrante, abrangendo aspectos da morfometria e da morfologia, que, analisadas e associadas aos materiais que as compõem, podem ser interpretadas em termos de tendências de processos, atuais e pretéritos (COLTRINARI, 2011; RODRIGUES, 1997; TRICART, 1965).

A legenda baseou-se nos mapas geomorfológicos do Plano de Manejo da APA da Várzea do Rio Tietê (FF, 2013), de SANTANA (2008) e de LUZ; RODRIGUES (2015), considerando três subsistemas morfogenéticos das planícies fluviais meândricas: canal (rio ativo, meandros abandonados, barras arenosas laterais e centrais); planície de inundação (cordões marginais convexos inativos e diques, backswamps e nível da planície); e terraços (terraços baixos e altos). A representação cartográfica baseou-se nas propostas de DEMEK (1972), GUSTAVSSON; KOLSTRUP; SEIJMONSBERGEN (2006) e TOONEN (2013), compondo simbologias que representassem, prioritariamente, as formas da planície e as texturas dos materiais. A análise centrou-se nas morfologias e materiais superficiais identificados, abrangendo-se a morfodinâmica e a morfogênese nas principais interpretações (COLTRINARI, 2011; TRICART, 1965). 


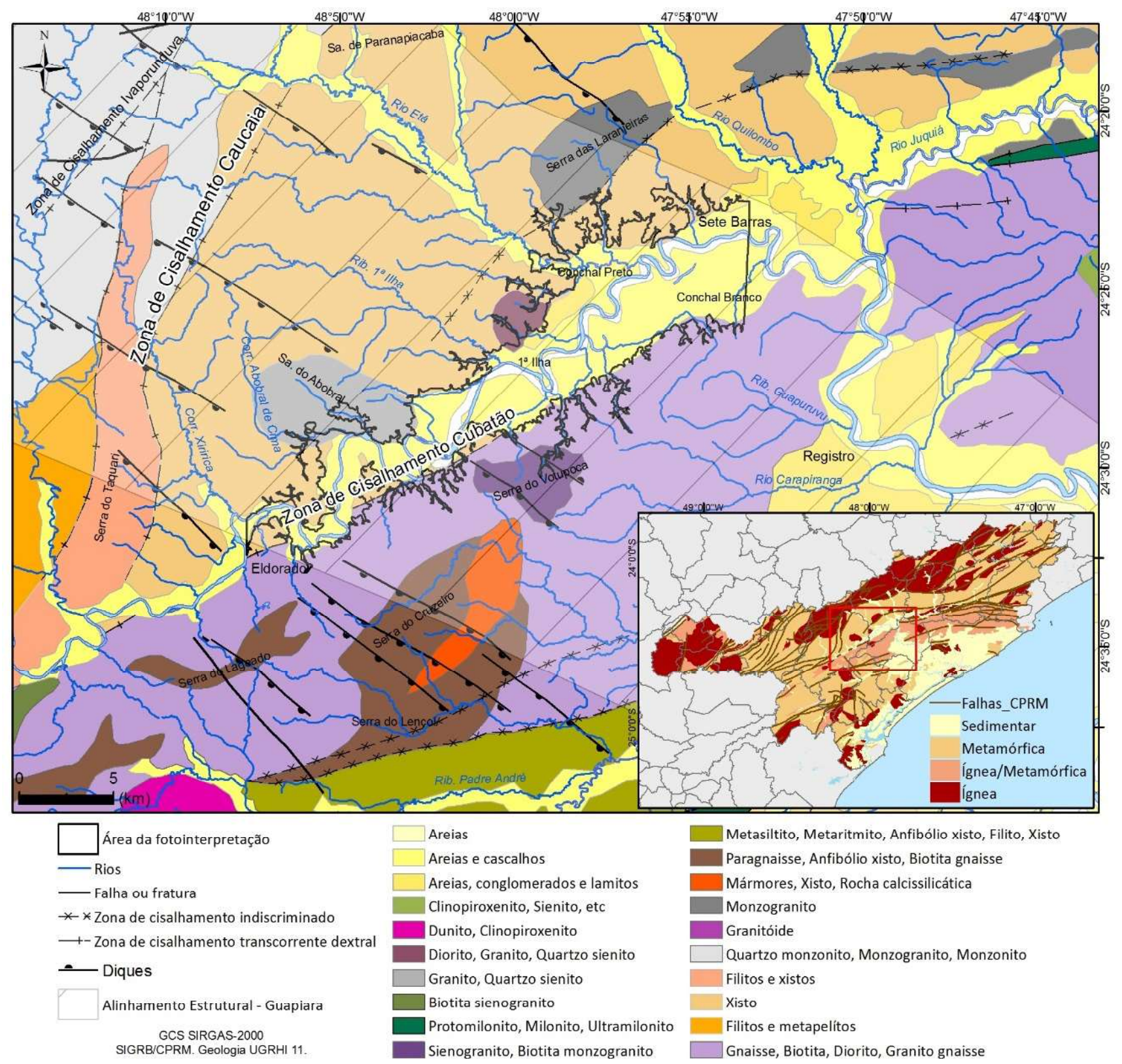

Figura 3 - Unidades litológicas e estruturas da área de estudo e entorno (SIGRB, 2017).

A produção do mapa geomorfológico incluiu fotoleitura e fotointerpretação morfológica a partir de estereoscopia analógica de 17 fotos aéreas, em escala 1:25.000 (EMPLASA, 2010/2011), utilizando a área útil das respectivas fotografias e estereoscópio de bolso (Figura 4). Em SIG, procedemos com registro espacial, restituição e representação de acordo com a legenda escolhida. As interpretações e revisões de limites incluíram campanhas de campo e a legenda foi sucessivamente modificada com base na interação gabinete-campo-gabi- nete. A morfologia e a morfometria foram apoiadas em planialtimetria oficial, 1:10.000 (IGC, 2010/2011;2015). Os dados secundários utilizados foram: mapeamentos geomorfológicos e geológicos de ROSS; MOROZ (1997) e IPT (1981), em escala 1:500.000 e 1:750.000, respectivamente, e mapeamentos geológicos da CPRM em 1:750.000 e 1:100.000 (CPRM, 2013;2014) e dados da Mineropar ( $\approx 500.000)$ (SIGRB, 2017). Na escala do setor ESB, o trabalho de SANTANA (2008) foi a principal referência na definição da legenda. 


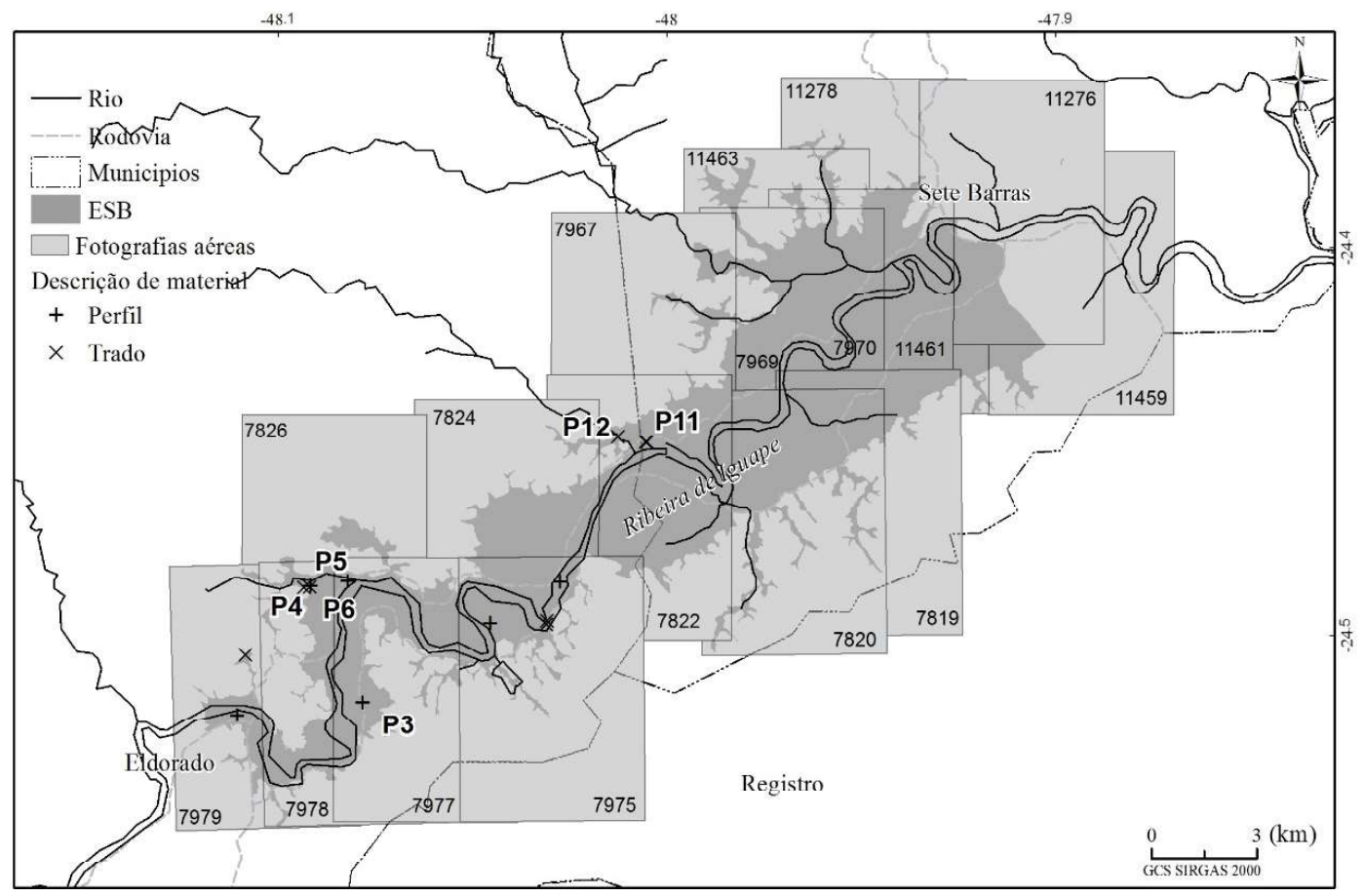

Figura 4 - Fotografias aéreas centrais e pontos de análise de material.

Em ambiente SIG foram utilizados registros espaciais sobre o Sistema de Referência Geocêntrico para as Américas 2000 (SIRGAS 2000). Definiu-se como referência o sistema de coordenadas geográficas (GCS), uma vez que a área de estudo abrange os fusos UTM 22 e 23. Para cada área útil restituída, foram identificados visualmente de 7 a 10 pontos de controle (GCP-Ground Control Points) baseados em elementos notáveis verificados nas ortofotos de 2010/2011 (EMPLASA, 2010/2011), utilizadas como base ao registro e georreferenciamento dos overlays, distribuindo-os uniformemente. Para reduzir as distorções produzidas no registro espacial, utilizamos equação polinomial de primeira ordem ao retificar cada overlay. Ainda que ajustes não lineares, normalmente, produzam menores erros em torno dos GCPs, essa função polinomial resulta em erros mais bem distribuídos ao longo da faixa registrada, conservando propriedades geométricas de locais afastados. Ainda em gabinete, os limites morfológicos foram ajustados a bases topográficas sistemáticas (1:10.000 PEC A) (IGC, 2010/2011;2015) e ao Modelo Digital de Terreno (1:25.000, PEC A) (EMPLASA, 2010/2011). Realizaram-se seis campanhas de campo para checagem de morfologias e limites mapeados e levantamento de materiais superficiais. Os trabalhos de campo foram feitos entre 17 e 19/12/2015, 16 e 19/02/2016, 05 e 07/09/2016, 29/11 e 01/12/2016, 12 e 14/12/2016, 30/01 e 02/02/2017.

Estudos sobre as características sedimentológicas e pedológicas da área de estudo são escassos, sendo as principais contribuições aquelas produzidas por BIGARELLA; MOUSINHO (1965a), MELO, MARIO SERGIO DE (1990) e SANTANA (2008). Para levantamento dos materiais foram realizadas descrições tátil-visuais de perfis, trincheiras e sondagens com trado manual, distribuídos em 14 locais nos distintos compartimentos morfológicos (Figura 1). Essa fase obedeceu ao roteiro de descrição de elementos sedimentológicos prioritariamente (BENITO; THORNDYCRAFT, 2004), com identificação e descrição de camadas, suas transições, cor predominante, granulometria, estruturas sedimentares, coesão do material e grau de compactação. Complementarmente, realizou-se o levantamento de elementos pedológicos (SANTOS et al., 2005) com descrição de estrutura pedológica, quantidade de matéria orgânica, raízes e presença de feições redoximórficas. Os materiais de canal foram descritos com base em granulometrias dos sedimentos de fundo do leito obtidas por sondagens à percussão.

Os overlays foram digitalizados, registrados e seus conteúdos vetorizados em SIG (ArcMap 10.5), para então realizarem-se as checagens de campo. Os resultados da restituição morfológica e dos levantamentos de material foram compilados em SIG com as informações de solo e geologia. As quantificações relativas à área e níveis topográficos foram obtidas por meio de SIG. As análises subsequentes ao mapeamento foram realizadas primeiramente por associação espacial entre as morfologias da planície e os materiais. 
Procedeu-se com a caracterização da variedade e espacialidade das morfologias destacando o arranjo entre elas e a associação entre formas e materiais superficiais esperados, a partir dos quais foram elaboradas proposições sobre tendências espaciais de processos hidromorfodinâmicos. Tais análises e associações foram pautadas em alguns dos principais referenciais teórico-metodológicos da geomorfologia fluvial para sistemas meândricos (ALLEN, J. R. L. , 1965; ALLEN, J. R. L., 1966; BRIDGE, 2003; CHOW, 1959; CHRISTOFO-
LETTI, 1981; CRICKMAY, 1974; ERSKINE, 1992; HOOKE, 1995; KNIGHTON, 1998; LEOPOLD, LUNA B.; WOLMAN, 1957; LEOPOLD, L. B.; WOLMAN, 1960; LEOPOLD, L. B.; WOLMAN; MILLER, 1964; MIALL, 1978; MORISAWA, 1985).

\section{Resultados}

O mapa geomorfológico da planície fluvial do baixo rio Ribeira de Iguape é apresentado na Figura 5.

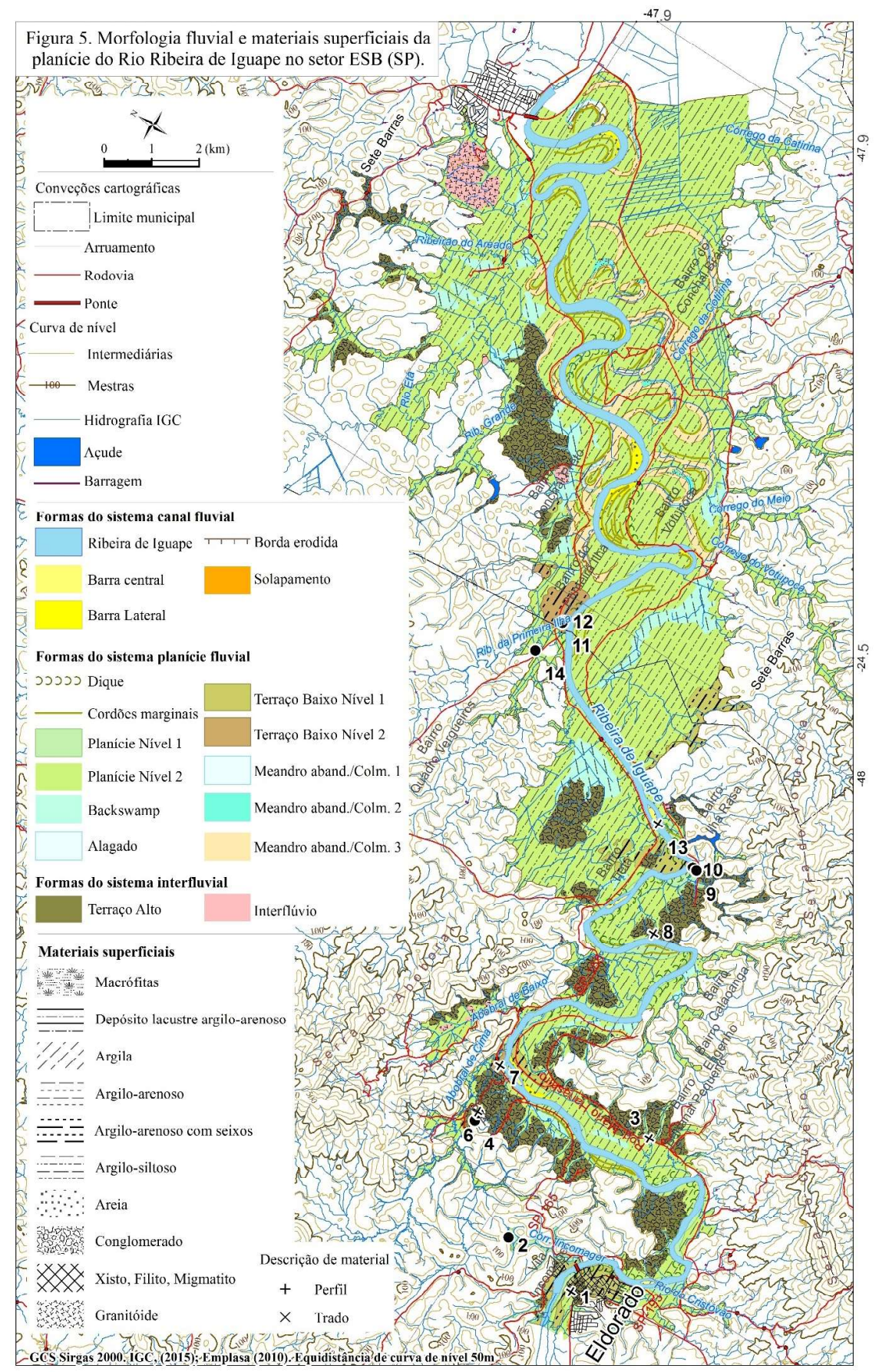

Figura 5 - Morfologia fluvial da planície do Rio Ribeira de Iguape no setor ESB (SP). 


\section{a) Canal Fluvial}

O setor $\mathrm{ESB}$ possui $\approx 100 \mathrm{~km}^{2}$ de área e o fundo de vale se estende na direção preferencial SW-NE por $22,7 \mathrm{~km}$, enquanto a extensão pelo canal principal é igual a 49,6km, resultando índice de sinuosidade de $2,2 \mathrm{~km} / \mathrm{km}$. O gradiente total de $9 \mathrm{~m}$ (16 a $7 \mathrm{~m}$ de altitude) lhe confere declividade de $0,00018 \mathrm{~m} / \mathrm{m}$. A distribuição e dimensão das morfologias identifica dois trechos: montante (desde a cidade de Eldorado ao bairro da Ilharasa/Votupoca) e jusante (Ilharasa/Votupoca até a cidade de Sete Barras). À montante, a sinuosidade apresenta mudanças abruptas de direção do fluxo em ângulos agudos e segmentos retilíneos; a planície é significativamente mais estreita em comparação ao setor de jusante. Neste, o rio assume traçado tipicamente meandrante, com alças caracteristicamente senoidais e evidências morfológicas de intensa migração lateral.

No setor de montante os indicativos de movimentação do canal por migração lateral restringem-se à presença de alguns cordões laterais pouco elevados $(<1 \mathrm{~m})$. Neste trecho, ocorrem afloramentos de diques de diabásio dentro do canal fluvial, observados em campo. O padrão de sinuosidade altera-se, significativamente, de montante $(1,12 \mathrm{~m} / \mathrm{m})$ à jusante $(2,25 \mathrm{~m} / \mathrm{m})$.

O formato das seções transversais levantadas no setor de montante tende a ser mais irregular, ora com formatos trapezoidais, ora retangulares e até triangulares, que refletem o traçado mais tortuoso do canal principal neste trecho e a ocorrência de afloramentos. No setor de jusante, as seções transversais tendem a apresentarem-se triangulares habituais em sistemas meândricos com aprofundamento na margem côncava e banco sedimentar na convexa. As barras arenosas centrais puderam ser distinguidas em dois tipos básicos: ilhas fluviais e bancos arenosos. Estes últimos são depósitos de material móvel predominantemente não-coesivos no centro do canal, ligeiramente acima do nível d'água. A instabilidade do material produz formas instáveis.

As ilhas são formadas por sedimentos consolidados com fixação de vegetação e, portanto, tendem a ser mais estáveis. No setor ESB estão presentes ilhas e barras arenosas, sendo que todos os exemplares se localizam no setor de montante. As barras centrais variam de 100 a $587 \mathrm{~m}$ de extensão, e 25 a $112 \mathrm{~m}$ de largura. $\mathrm{O}$ formato longilíneo guarda razões quase constantes entre comprimento e a largura: quanto mais comprida, maior tende a ser sua largura e mais largo tende a ser o próprio canal fluvial. As duas barras centrais mais longas de 587 e
$568 \mathrm{~m}$ possuem larguras de 220 e $200 \mathrm{~m}$, respectivamente, produzindo razão de comprimento/largura de $\approx 0.4$.

Internamente às barras, uma série de formas mais detalhadas se desenvolvem, algumas delas refletindo processos de fundo de canal (Figura 6). A porção de montante das ilhas é composto por materiais friáveis, em geral formado por granulometrias de areias a cascalhos de fontes petrográficas diversas e razoável grau de seleção textural. Apresenta ainda evidências de linhas erosivas em frente de deposição, constituindo setor de desenvolvimento da forma (CPRM, 2016). Estes depósitos são depositados por fluxo fluvial efetivo de média a elevada competência e conservam estruturas sedimentares e estratigráficas que permitem distinguir camadas relativas a distintos eventos de acreção.

As barras laterais concentram-se no setor de jusante do trecho estudado. Possuem comprimentos que podem variar de 300 a $2.000 \mathrm{~m}$, que tendem a ser diretamente correlacionados ao tamanho do raio meândrico (correl=0,77). As larguras dessas formas são variáveis (de poucos metros a até $100 \mathrm{~m}$ ), as quais tendem a ser mais delgadas nas porções de montante e ligeiramente mais amplas à jusante, prolongando-se em plumas de sedimentos no final da alça meândrica. As declividades das barras laterais raramente superam $2^{\circ}$. São formas muito dinâmicas e suas mobilidades podem ser explicadas sumariamente pela potência do fluxo fluvial, por seu padrão de escoamento no interior do rio em fluxo helicoidal e pela carga sólida predominante.

Os materiais que formam essas morfologias são, fundamentalmente, areias bem selecionadas, de textura média a grossa (-0,5phi), e cascalhos, característicos de transporte de leito por arraste e rolamento, redundando pacotes inconsolidados, com ausência de finos e matéria orgânica. A elevada energia dos fluxos fluviais que constantemente ocorrem nestes sistemas também é responsável pela constante retirada e ciclagem do material.

As formas de margens erosivas são relativas às bordas do canal fluvial que sofrem solapamento e queda. São marcadas por rupturas de declividade entre o nível d'água e a planície. Concentram-se no setor de jusante do canal, principalmente nas margens côncavas dos meandros. Podem se extender por até $\approx 2,5 \mathrm{~km}$, atingindo alturas de $6 \mathrm{~m}$ em relação ao nível médio das vazões. Conforme ocorre erosão da base dessas margens, o material de recobrimento se desestabiliza e cede, definindo bordas solapadas, onde ocorrem acúmulos de sedimentos dentro do canal fluvial. 

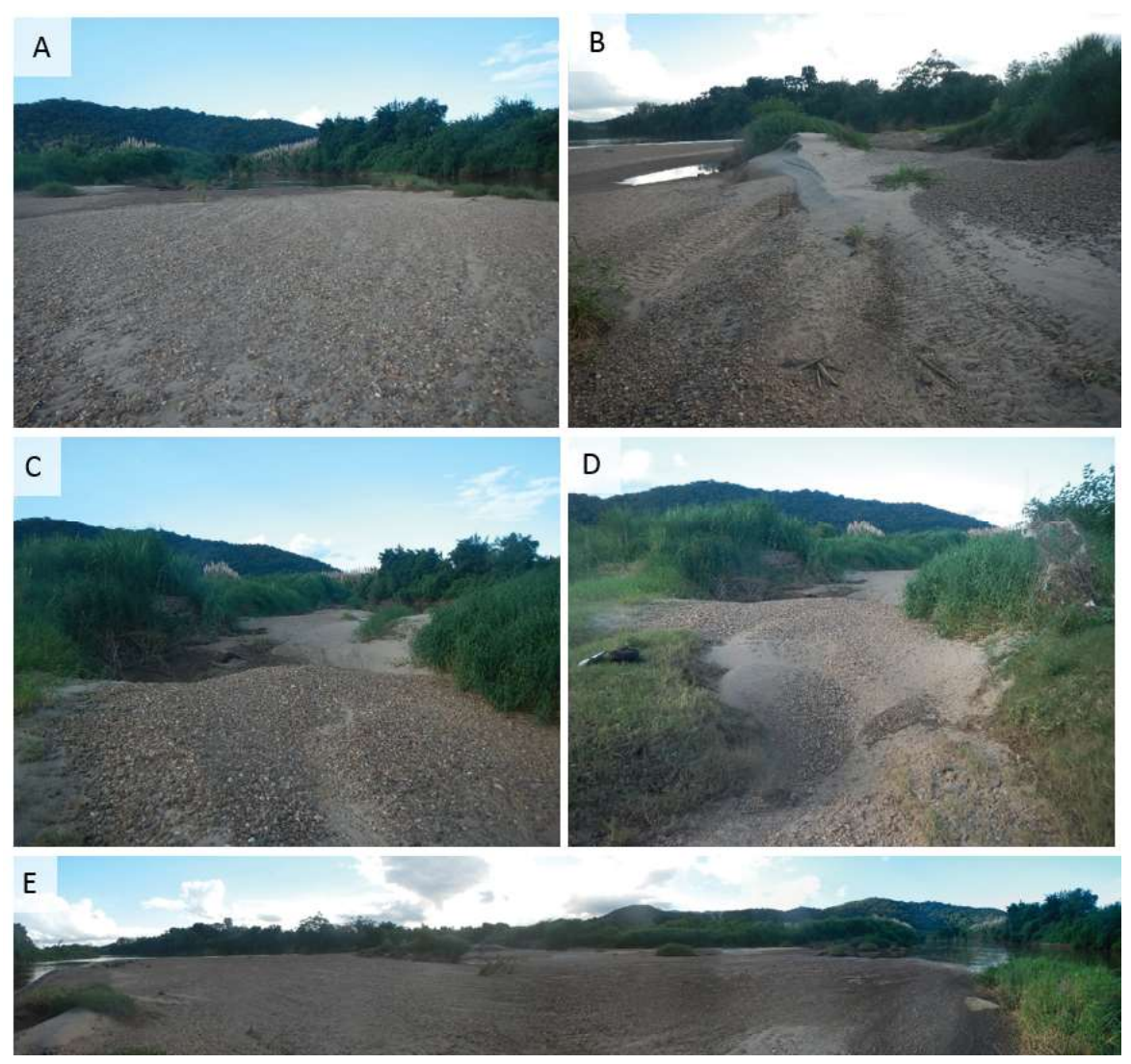

Figura 6 - Promontório da barra de Votupoca. (A) Linhas erosivas em frente de deposição; (B) macrodunas vegetadas; (Ce D) macro-ondulações que assinalam caminhos preferenciais da água; (E) acumulações preferenciais de cascalhos e de argilas em embaciamentos no interior das barras.

\section{b) Planície fluvial}

A Planície de inundação é formada por superfície com dois níveis altimétricos, diques fluviais, cordões marginais convexos e meandros abandonados. $\mathrm{O}$ conjunto destas formas representa $76 \%\left(76,2 \mathrm{~km}^{2}\right)$ de toda área mapeada. A planície apresenta altitude média de $17 \mathrm{~m}$ (acima do NMM) considerando todo o trecho estudado, apresentando amplitude de $17 \mathrm{~m}$ (de $28 \mathrm{~m}$ a $11 \mathrm{~m}$ de altitude). À montante tende a ser mais estreita com larguras entre $300 \mathrm{~m}$ e $1.000 \mathrm{~m}$. A partir do bairro do Votupoca amplia-se significativamente até assumir larguras raramente inferiores a $2.000 \mathrm{~m}$, com valores máximos de $6.000 \mathrm{~m}$ nas proximidades na cidade de Sete Barras (Figura 7). A dinâmica de migração lateral do canal, o escoamento superficial na planície e os processos erosivos e deposicionais antropogênicos representados por sistemas de drenagem artificiais produzem descontinuidades topográficas na planície que intensificam as ondulações característicos dos perfis de cordões marginais e das depressões de backswamps.

Proximamente ao canal atual desenvolvem-se formas topograficamente rebaixadas que definem o primeiro nível de planície, abatidos em relação ao segundo nível. São compartimentos longilíneos ou arqueados, localizados entre o canal e a Planície Nível 2, com pouca diferença altimétrica em relação ao canal. A descontinuidade de planície Nível 1 com a Planície de Nível 2 é definida por mudança de declividade côncava. O compartimento de Planície Nível 2 define a superfície principal da planície, incluindo cordões laterais, backswamps e diques.

A planície do rio Ribeira de Iguape é composta de pacotes Holocênicos constituídos por lentes de deposição fluvial com granulometria predominantemente areno-siltosa. Tanto em profundidade, quanto horizontalmente, estes sedimentos são marcados pela heterogeneidade (GRIGOROWITZCH,2015). A descrição de seus materiais realizada por meio de tradagem manual (Figura 8) ilustra tal heterogeneidade. Por razões operacionais não foram realizados levantamentos de amostras de materiais na planície de nível 1 , apenas nos compartimentos morfológicos das planícies de nível 2. 

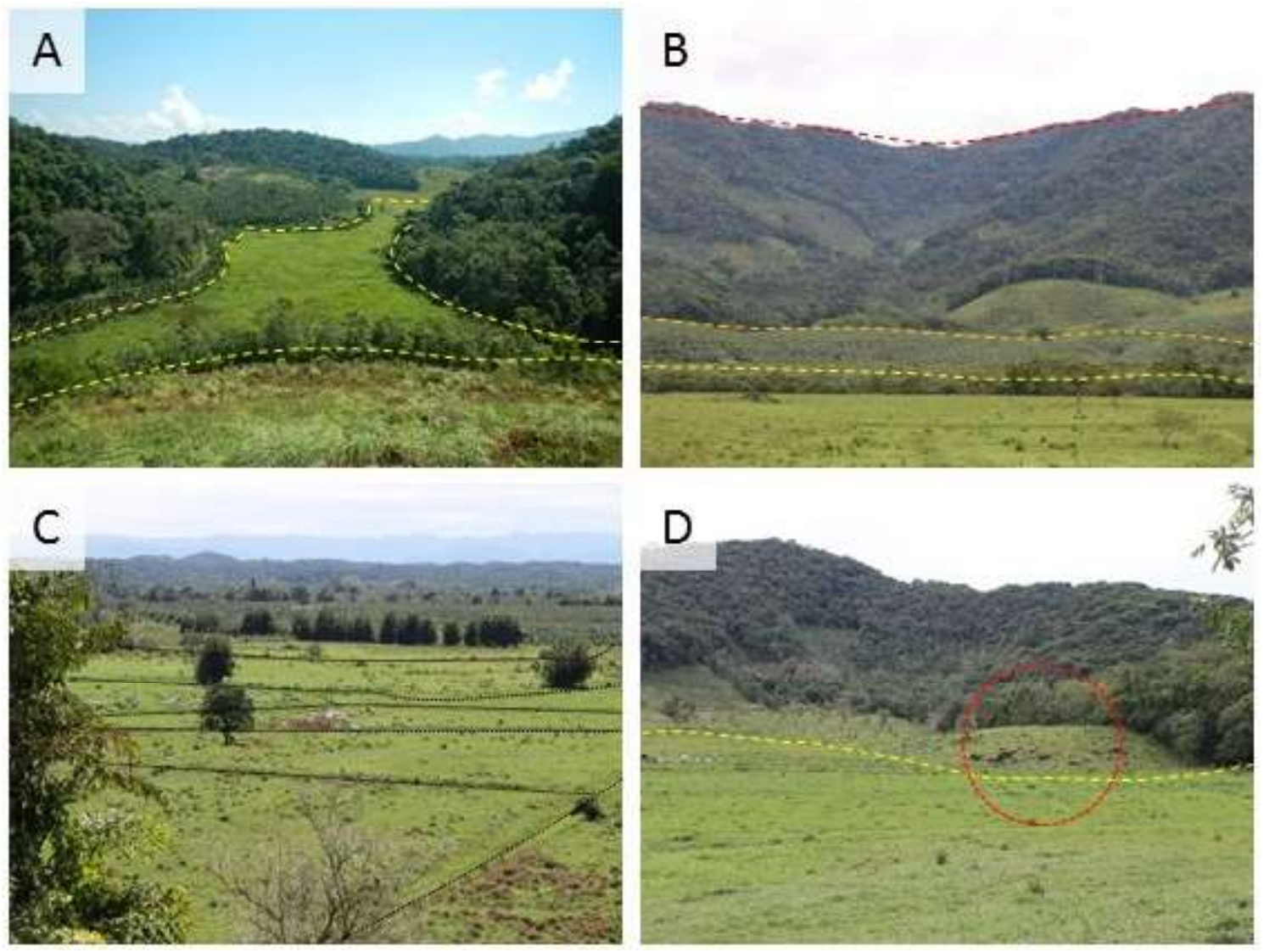

Figura 7 - Exemplos de planicies fluviais do canal principal e afluentes, mapeadas no setor ESB.

A - Ruptura côncava com a base da vertente. B - Indicações: amarelo, ruptura côncava entre planície e base da vertente; laranja, superfície de morrotes abatidos ocupados por bananeiras (20 a 30m acima da planície); vermelho, superfície cimeira sustentada pelo granito Votupoca (>120m de altitude). C - Valas de drenagem antropogênicas. D - Indicações: amarelo, ruptura côncava com base de vertente; vermelho, tálus e afloramento de caos de blocos.

Na planície do córrego Abobral, observa-se em P4, material constantemente saturado com características de coloração que sugerem intensa redução de cátions (A), composto por sedimentos com texturas predominantes silto-arenosa à areno-argilosa, podendo ocorrer seixos quartzosos de até $5 \mathrm{~mm}$ de diâmetro, maior a partir dos $40 \mathrm{~cm}$ de profundidade. Podem se desenvolver blocos irregulares subarredondados, com de grumos de média coesão nas camadas mais superficiais. O aumento da profundidade confere maior compactação e coesão do material, o que é acompanhado pelo decréscimo de matéria orgânica, raízes e quantidade de macroporos. Ao longo da vertical do ponto $\mathrm{P} 4$ a variação da cor está associada às feições de oxidação de ferro do tipo massa que se distinguem em termos de sua densidade, tonalidade e tamanho das pátinas alaranjadas. As características destas feições indicam a dinâmica de flutuação do nível saturado e a oscilação desta saturação, com a frequência aproximada de alguns meses do ano com maior tendência à redução, ou mesmo, depleção de ferro.

Em P5, obtido em compartimentos morfológicos relativamente melhor drenados, o material tem matriz oxidada, assumindo tonalidade bruno-escuro a bruno-claro. A textura predominante é de areia fina, variando à argila-arenosa com seixos de até $5 \mathrm{~cm}$. Observou-se tendência ao desenvolvimento de blocos irregulares subangulares, de moderada estruturação e baixa pegajosidade. A concentração de matéria orgânica tende a diminuir com a profundidade até definir camadas de predominância mineralógicas a partir de $40 \mathrm{~cm}$ de profundidade, sendo acompanhada da diminuição da densidade de raízes e da porosidade. As feições de hidromorfia denotam acumulações de ferro de tipo massa principalmente ao redor dos fragmentos grosseiros, como seixos e cascalhos. 

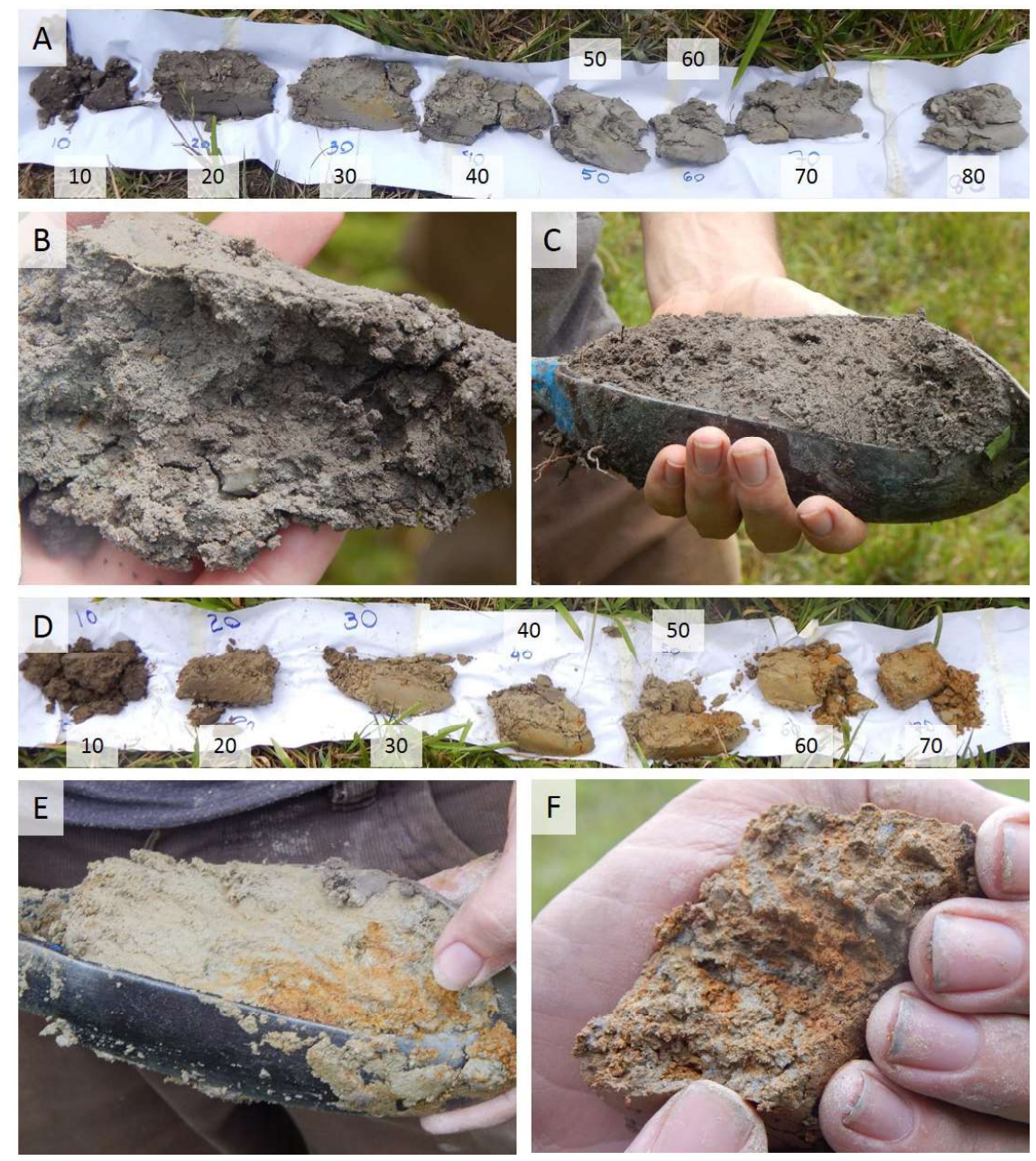

Figura 8 - Materiais de planície do córrego do Abobral. P4 (A, B, C) e P5 (D, E, F).

A-Sondagem de $80 \mathrm{~cm}$. B-20cm de profundidade, blocos irregulares, fissuras angulosas e gretas de concreção. C-30cm de profundidade, textura silto-arenosa e concentração de matéria orgânica. D-Sondagem de $70 \mathrm{~cm} ; E-30 \mathrm{~cm}$ de profundidade, material compactado de estrutura homogênea, com aumento de feições de hidromorfia. F - 50cm de profundidade, aspecto variegado do material, com concentração de feições redox em matriz reduzida.

Os diques configuram-se como proeminências nas margens plenas do canal, atual ou antigo. No setor ESB, estas morfologias não estão presentes de modo abundante, concentrando-se no trecho de montante. Localizam-se habitualmente na borda do canal atual, coincidindo a base das formas de diques com a margem do canal fluvial. Em termos morfométricos, eles tendem a ser lateralmente descontínuos, estendendo-se de algumas centenas de metros a até $3 \mathrm{~km}$ de extensão. A declividade do front do dique estão acima de $30^{\circ}$, enquanto o reverso desenvolve-se em rampas alongadas com mudança de declividade de 4 a $2^{\circ}$.

Os cordões marginais convexos são depósitos de canal que resultam da migração lateral do rio e, por isso, são mais frequentes no trecho de jusante
(Figura 9). Associam-se às barras arenosas laterais e podem assumir diversos comprimentos, espessuras, amplitudes e graus de arqueamento, conforme o local de desenvolvimento e a alça de meandro a que se vincula. No trecho de jusante, onde são mais abundantes, estas formas associam-se ao canal ativo e a meandros abandonados. Tendem a ser espacialmente descontínuas, provavelmente devido a processos erosivos decorrentes de ações de drenagens efêmeras por fluxos pluviais e de inundação. Em casos excepcionais podem atingir até $1.500 \mathrm{~m}$ de extensão e até $25 \mathrm{~m}$ de largura. No trecho de montante, onde estas formas são menos frequentes, tendem a ser mais retilíneas, variando entre 430 a $1050 \mathrm{~m}$ de comprimento, e, em alguns casos, abrangendo mais de $20 \mathrm{~m}$ de largura. 

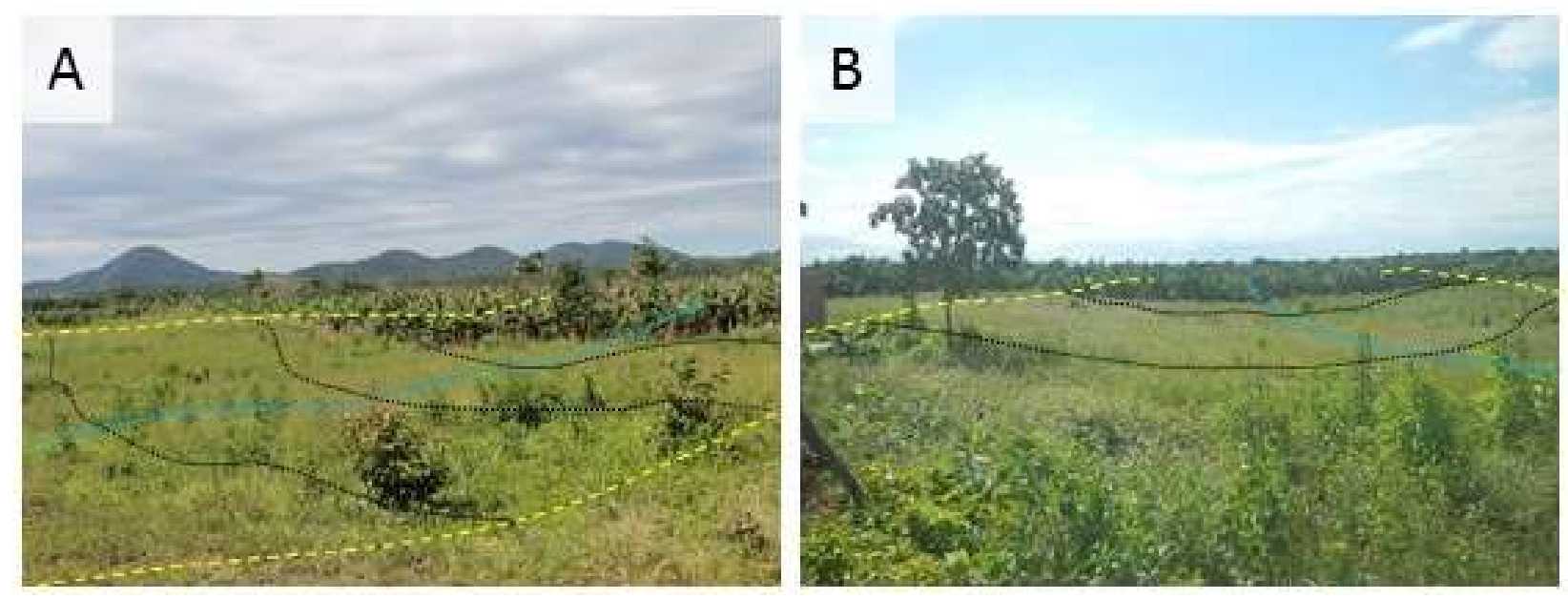

Figura 9 - Exemplos de cordões marginais convexos mapeados no setor ESB.

Indicações: amarelo, crista dos cordões marginais convexos; azul, eixo das depressões entre cordões 3 a 4m abaixo da crista; preto, seções transversais esquemáticas de tais superficies.

Os meandros abandonados ocorrem em sua totalidade no trecho de jusante e podem se apresentar com diferentes níveis de sedimentação. Ocupam 5\% da área dominada por morfologias de planície fluvial (equivalente à $4.891 .532 \mathrm{~m}^{2}$ ), proporção que sobe a $11 \%$ quando se considera apenas o cinturão meândrico. Em termos dos materiais que compõem estas formas, as condições de saturação dos depósitos favorecem a conservação de feições sedimentares e erosivas, e mantém a organização do material, podendo permitir a identificação de variações texturais mais delgadas, acamamentos, tendências de laminações e acúmulos de M.O. Em geral, estas camadas são marcadas por padrões de sucessão entre camadas argilo-arenosa ou argilo-siltosa recobertas por lâmina argilosa com elevada concentração orgânica, cuja identificação, em alguns casos são ratificadas por restos de fibras vegetais, fragmentos de carvão e coloração preta predominante. Estas laminações orgânicas podem variar de espessura, mas raramente ultrapassam $2 \mathrm{~cm}$, distribuídos de modo plano em relação à camada sobre a qual se deposita.

A quantidade de vezes em que os paleomeandros são solicitados em eventos de inundação determina seu grau de ativação. Estes graus indicam os caminhos preferenciais de conectividade hidráulica na planície, propriedade que descreve as trocas de matéria e energia entre os diferentes componentes e subsistemas envolvidos no sistema fluvial, e por meio das quais a dinâmica evolutiva do sistema opera (WOHL, 2016;2017). Os paleocanais com lagos são habitualmente mais profundos e suas separações do canal atual ainda estão em curso, por isso, são mais frequentemente ocupados por inundações do rio Ribeira de Iguape.

\section{c) Terraços}

$\mathrm{Na}$ área de estudo, o mapeamento geomorfológico identificou níveis terraceados se dividem em Terraços Altos e Terraços Baixos, ambos com exemplares mais significativos e conservados no setor de montante (Figura 10), onde há evidências de maior controle estrutural das formas. Foram identificados 21 exemplares de terraços baixos que caracterizam-se por mais de um intervalo altimétrico no trecho: Terraço Baixo Nível 1 ( 2 a $5 \mathrm{~m}$ de altura em relação à planície, ou seja, de 28 a $19 \mathrm{~m}$ de altitude) e Terraço Baixo Nível 2 (5 a 10m de altura em relação à planície, ou seja, 31 a $20 \mathrm{~m}$ de altitude), concentrando-se na margem esquerda no trecho de montante.

Os terraços altos totalizaram 77 unidades, com desníveis de 10 a $30 \mathrm{~m}$ sobre o nível principal da planície. Os terraços altos são superfícies aplainadas, em geral com declividades de até $6^{\circ}$, podendo apresentar dissecação vertical significativa. Localizam-se, preferencialmente, na retaguarda das planícies de inundação ou de níveis terraceados baixos, com contato em ruptura côncava na base e convexa no topo. À montante, estabelecem contato com os sistemas interfluviais de morros, em geral definindo mudanças côncavas de baixa declividade. A partir de seu front em direção à montante, estas superfícies podem apresentar uma diminuição altimétrica em rampa alongada. Possuem desníveis acima 
de $15 \mathrm{~m}$ sobre a planície de inundação de nível 2, e de 20 a $35 \mathrm{~m}$ das margens. Alguns compartimentos de terraços altos são tão elevados quanto os próprios sistemas interfluviais adjacentes, e devido à sua esculturação por dissecação fluvial, resultam em morfologias de colinas

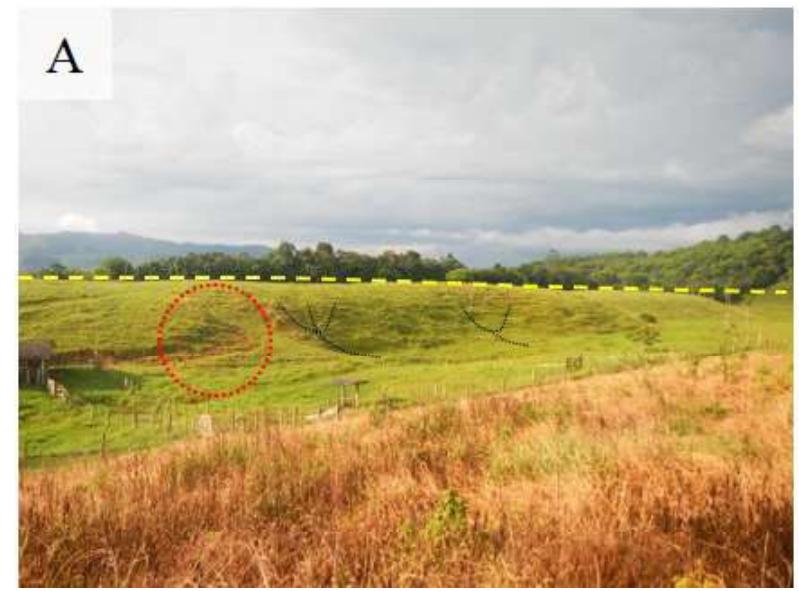

alongadas. $\mathrm{O}$ exemplares de terraços altos ocorrem em ambos os flancos do vale (Figura 11, perfil A-A'), em alguns casos, estão presentes apenas em um dos lados (Figura 11, perfil B-B'). Apresentam superfícies suavemente convexizadas devido à erosão das bordas.

Figura 10 - Niveis de terraços no setor ESB.

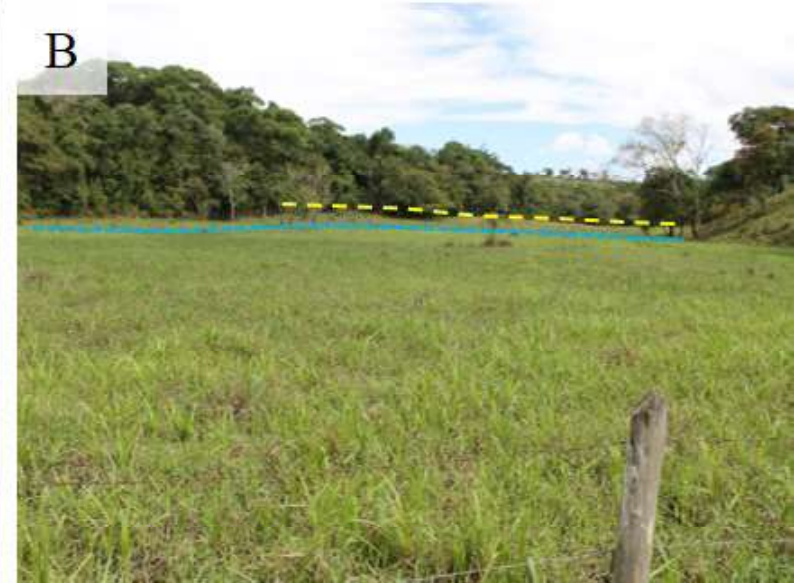

$A$ - Terraço alto ( $\approx 15 \mathrm{~m}$ de altura) dissecado por frentes abauladas e erodido por pastoreio. Indicações: amarelo, superfície de terraço alto; preto, frente de erosão; vermelho, terracetes de pisoteamento. B - Terraço baixo em retaguarda da planície do córrego do Abobral.. Indicações: amarelo, superficie de terraço baixo; azul, nivel de base local.
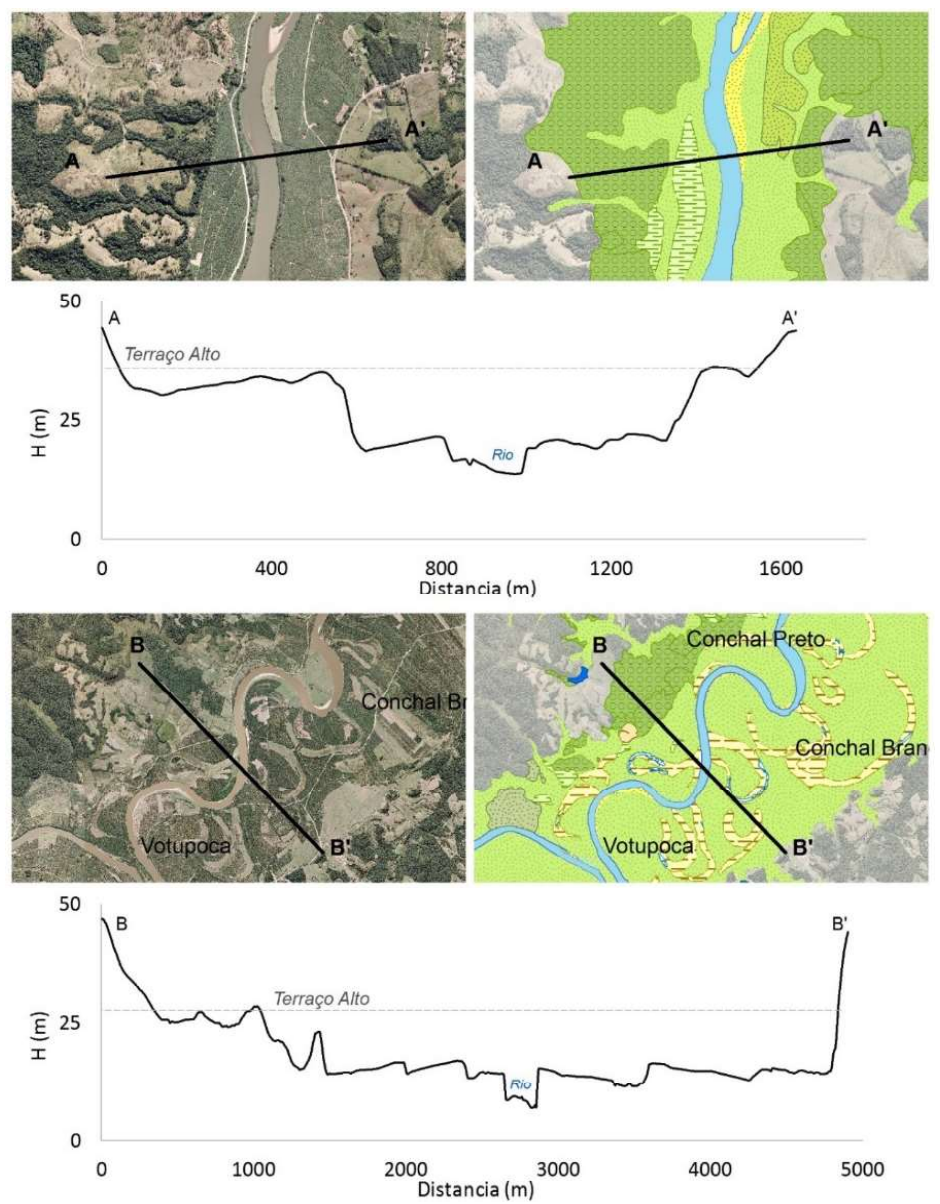

Figura 11 - Exemplos de seções transversais de vale incluindo Terraços Altos. 


\section{Geomorfologia Fluvial do Baixo Ribeira de Iguape, São Paulo, Brasil}

Quanto aos materiais, os terraços baixos de nível 1 (com desníveis de 2 a $5 \mathrm{~m}$ em relação à planície), compõem-se de matriz argilo-siltosa a argilo-arenosa, com fase rudácea abundante, de seixos subarredondados e calhaus quartzosos dispostos caoticamente até $30 \mathrm{~cm}$ de profundidade (Figura 12). A estrutura sedimentar é homogênea a levemente laminada, em camadas muito compactadas, sem poros, pouca matéria orgânica e baixa densidade de raízes, caracterizando camadas mineralógicas de transição difusa. A partir de $30 \mathrm{~cm}$ da superfície assume tonalidade acinzentada (gley) e diminuindo a quantidade de matéria orgânica e atividade biológica, aumentando simultaneamente a frequência e os tamanhos dos seixos maiores com distribuição caótica.

Os terraços baixos nível 2 (com desníveis de 5 a $10 \mathrm{~m}$ sobre a planície) apresentam características sedi- mentológicas distintas em relação ao seu material (Figura 13). Em geral, são formados por espessos pacotes homogêneos de textura argilo-arenosa à franco-arenosa, com matriz oxidada (bruno-amarelado-claro) e incipiente desenvolvimento pedogenético (Neossolo Litólico e Cambissolo) em blocos irregulares. Em P11 foram tradados $100 \mathrm{~cm}$ nos quais observou-se horizonte A enterrado de coloração bruno-amarelado-claro $(\approx 20 \mathrm{~cm}$ da superfície), com textura argilo-arenosa, estruturas em bloco, de resistência moderada e porosidade abundante. Conforme aprofunda-se verticalmente no perfil aumenta-se a proporção de silte, coincidindo com o aumento de resistência e coloração acinzentada clara, e com surgimento de feições redox alaranjadas em massa (de baixo contraste). A partir dos $70 \mathrm{~cm}$ há aumento da concentração de seixos angulosos a subarredondados de composição quartzosa, alguns maiores de $2 \mathrm{~mm}$.

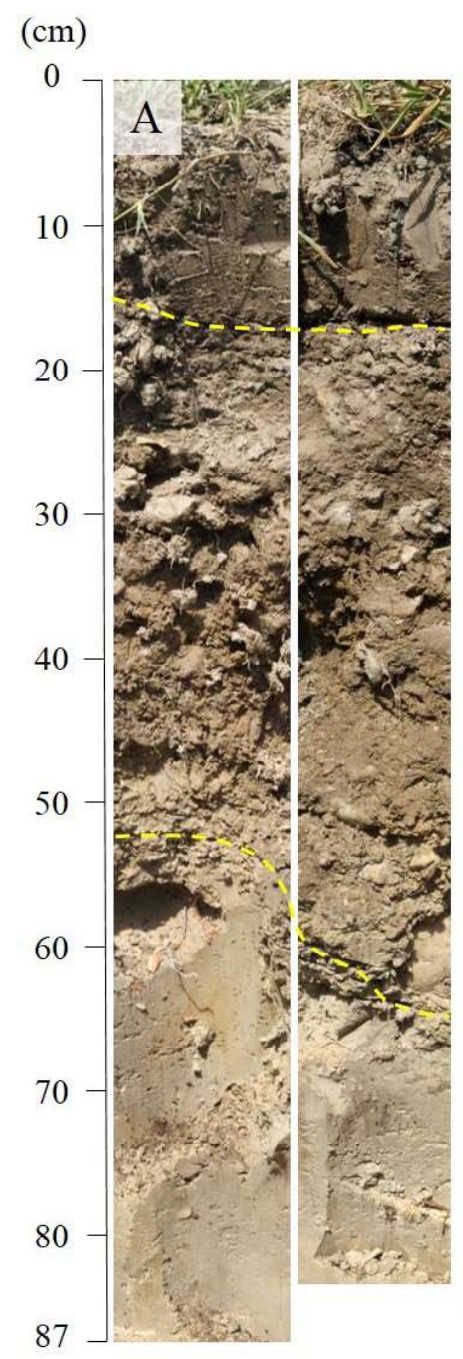

$15 \mathrm{~cm}$ de espessura, arenoso com pouco silte e argila. Transição claro, abrupto e irregular. Estrutura homogênea. Estrutura pedológica inexistente. Pouco resistente, de fácil penetração e escavação. Material friável. Bioturbação por raízes, mas baixa

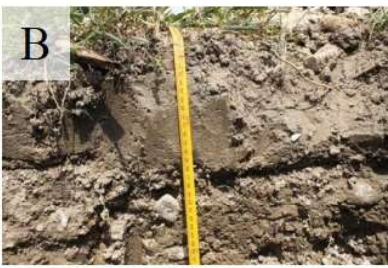
atividade de térmitas e minhocas

$40 \mathrm{~cm}$ de espessura, matriz areno-argilosa com muitos cascalhos e seixos. Transição claro, abrupto e muito irregular. Sem estrutura sedimentar aparente, camada rudácea, seixos subarredondados a arredondados, sem imbricação e direção de corrente. Disposição caótica de seixos. Estrutura pedológica inexistente. Muito resistente devido aos cascalhos e seixos. Pouco resistente, de fácil penetração e escavação. Matriz friável. Bioturbação por alguns caminhos de termitas. Diminuição da quantidade de raízes.

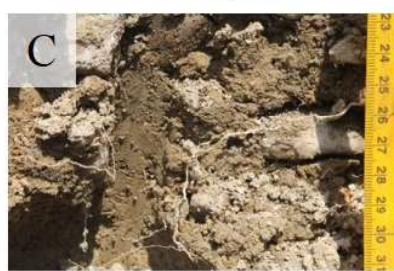

$32 \mathrm{~cm}$ de espessura, argiloso com areia fina e diminuição abrupta dos cascalhos e seixos mais grosseiros, mas concentração de fragmentos quartzosos fortemente intemperizados de até $5 \mathrm{~mm}$. Matriz areno-argilosa. Estrutura homogênea. Estrutura pedológica inexistente. Pouco resistente. $\mathrm{O}$ aumento de teor de argila deixa o material mais compactado, mas segue sendo friável. Pouquissima bioturbação. Ausência de raízes. Poucas fissuras.

Figura 12 - Trincheira em terraço baixo no vale do córrego do Abobral (P6). 


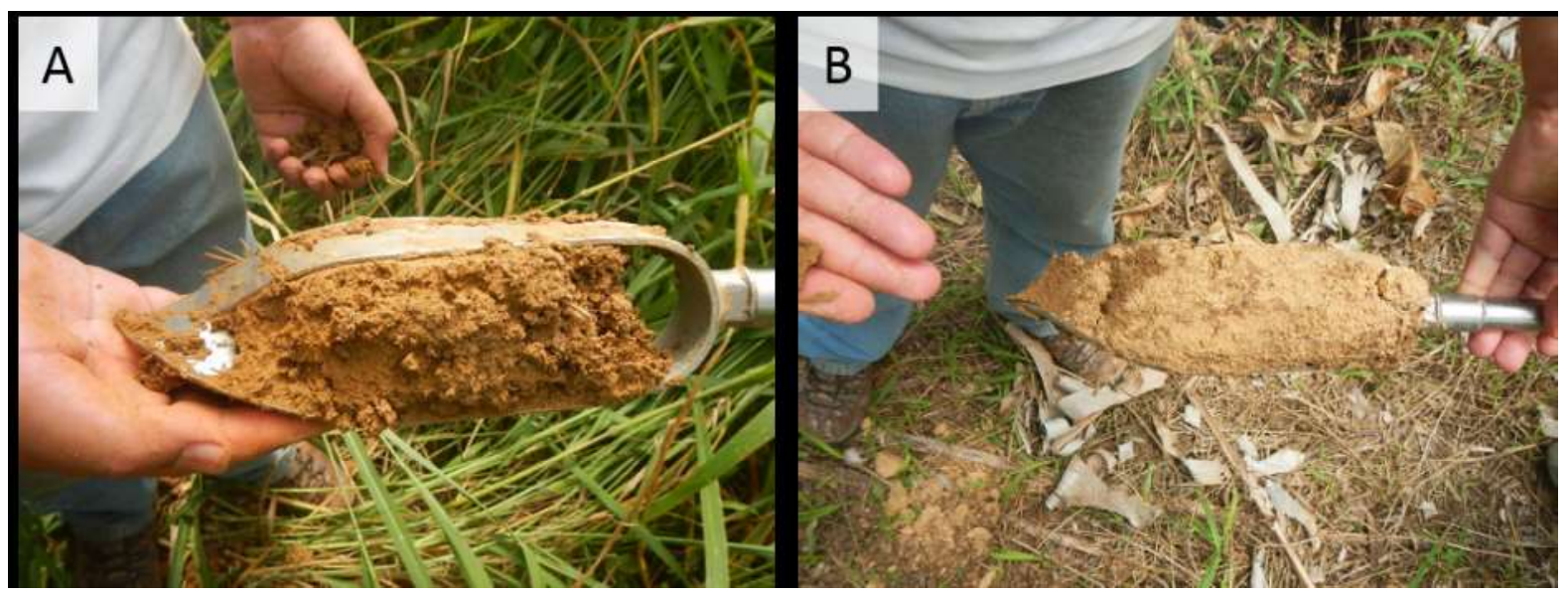

Figura 13 - Material de terraço baixo próximo à confluência entre Rio do Salto e o Ribeira de Iguape. P11 (A, ح40cm de profundidade) e $P 12$ ( $B, \approx 40 \mathrm{~cm}$ de profundidade).

Os materiais dos terraços altos correspondem aos pacotes da Formação Eldorado, ilustrado pela seção-tipo em Eldorado (Figura 14). Os sedimentos da Formação Eldorado representam sistemas deposicionais fluviais Pleistocênicos de fundo de rios entrelaçados (MELO, MARIO SERGIO DE, 1990). Os terraços altos denotam o limite das recentes inundações de maiores proporções ocorridas nas últimas décadas e que corresponde à dinâmica fluvial atual. Em depoimentos orais recolhidos de moradores, obtive-se que os limites espaciais que correspondem às cotas atingidas pelas maiores inundações recentes de 1997 e 2011 coincidiram com os limites formados pelas bases dos terraços altos em diversos locais ao longo do setor ESB.

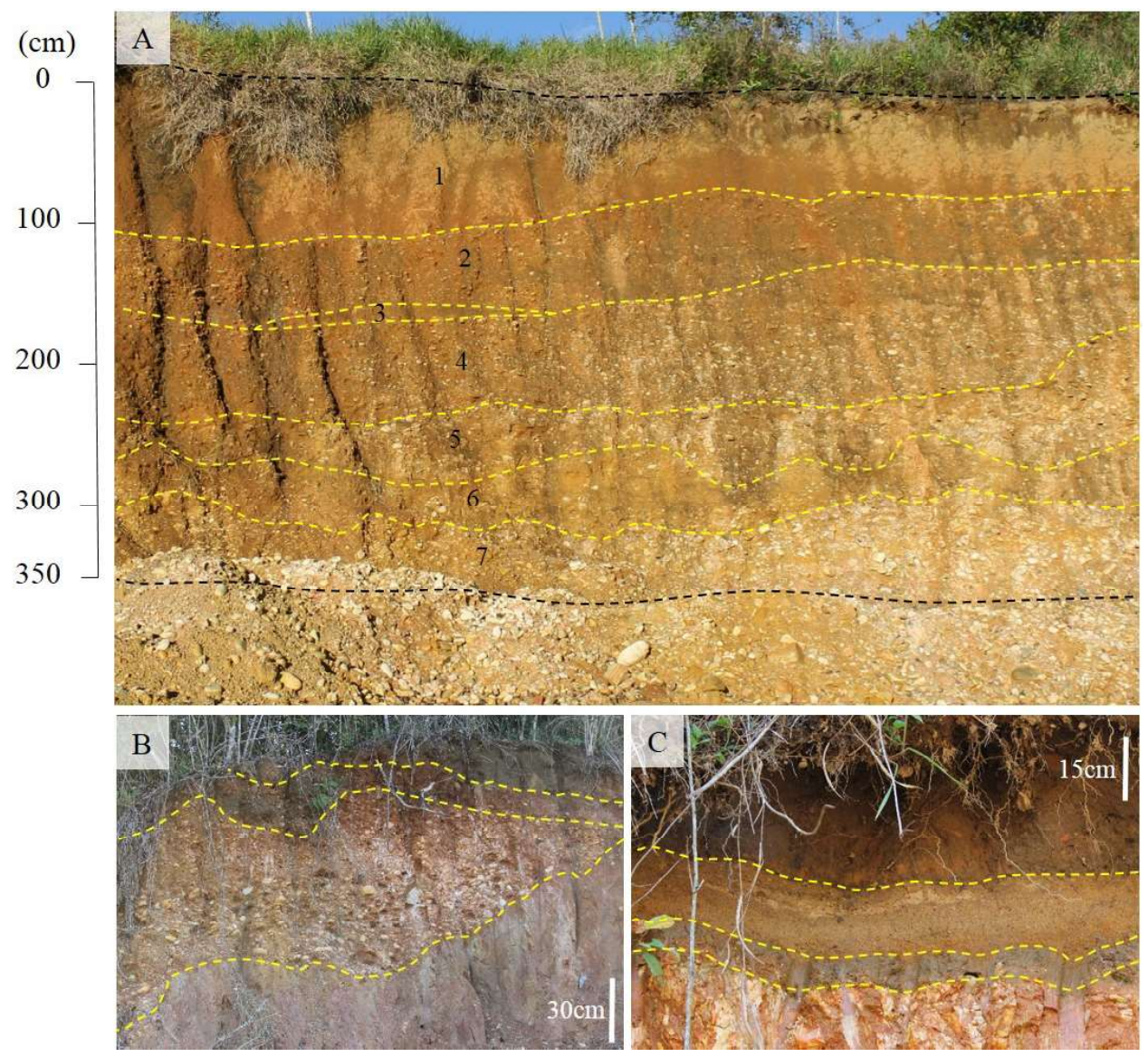

Figura 14 - Perfil de terraço alto em área de empréstimo de material (P3). 
A - Perfil $\approx 350 \mathrm{~cm}$ de espessura com 7 camadas, com granodecrescência ascendente com intercalações pelíticas (3 e 6) e camadas grosseira (2, 3, 5 e 7) em disposição caótica de grãos. B - Contatos entre ambientes de sedimentação, horizonte orgânico delgado $(<10 \mathrm{~cm})$ sobre fase rudácea de grãos imbricados, depositada diretamente no afloramento de migmatito, $\mathrm{C}$ - Descontinuidades litológicas. Perfil raso com horizonte orgânico (30 $\mathrm{cm}$ no topo do perfil) sobre camada franco-arenosa ( $15 \mathrm{~cm}$ de espessura), finamente laminada à ondulada; $\mathrm{e}$ camada argilo-siltosa, acinzentada ( $5 \mathrm{~cm}$ de espessura) com pátinas alaranjadas a amareladas.

\section{Discussões}

Do ponto de vista hidromorfodinâmico, a variabilidade de formas e de materiais implica distintas tendências de processos hidrodinâmicos em cada subsistema e em cada compartimento mapeado. Por exemplo, as formas erosivas de margens indicam que, no setor de montante, acima dos bairros de Ilharasa-Votupoca, há maior estabilidade das formas das margens em comparação às margens localizadas no setor de jusante. Esta estabilidade pode ser devida, em primeiro lugar, ao tipo de padrão de canal fluvial meândrico instalado à montante e, em segundo lugar, em função da presença mais significativa de vegetação nas margens. Complementarmente, a maior estabilidade das formas de margens permite a fixação da vegetação que, por sua vez contribui para a estabilidade das formas.

Por outro lado, no setor de jusante (à jusante do bairro Ilharasa-Votupoca) os processos erosivos de margem são de dimensões maiores e mais intensos, sendo a dinâmica de alteração do trajeto do canal influenciada pela própria migração lateral e por processos de abandono, como neck cut-off e, possivelmente, chute cut-off (avulsão).

Em algumas planícies de afluentes do rio Ribeira de Iguape, o processo de preenchimento por sedimentos fluviais elaborou superficies de deposição extremamente homogêneas quanto à topografia, como é o caso dos vales estreitos dos córregos Incomager, Abobral de Baixo, parte do rio Etá e tributários menores da margem direita; que remetem a formas análogas de vales afogados por represamento. Em contraposição à heterogeneidade pedológica e, principalmente, sedimentológica, esta homogeneidade é indicadora do controle hidráulico do rio Ribeira de Iguape sobre a sedimentação por inundação destas retaguardas, e sua variabilidade espacial é bem representada no mapeamento. Por outro lado, a dinâmica de migração lateral do canal no trecho de jusante, somada ao escoamento superficial na planície, produz descontinuidades topográficas no interior da planície, formada por rugosidades produzidas pelos cordões marginais, backswamps e dissecação do próprio nível da planície por afluentes do rio Ribeira de Iguape. Estas descontinuidades estão em parte contidas nas legendas de cordões laterais, paleocanais e bacias de decantação, mas há variações menores, generalizadas na escala de mapeamento.

Os principais mecanismos de elaboração de planícies meândricas atuais vinculam-se à migração lateral dos canais e à inundação. O mapeamento geomorfológico permite afirmar que no trecho de jusante do setor ESB a migração lateral é predominante, evidenciada pela presença de meandros abandonados, inexistentes no trecho de montante, e cordões marginais convexos que indicam a intensidade com que a migração tende a se processar. No trecho de montante, as formas fluviais predominantes, além do nível principal de planície, são backswamps, sugerindo que tendem a prevalecer intensos mecanismos de elaboração relacionados ao extravasamento do canal e posterior decantação.

No trecho de montante, o estreitamento do vale, por razões estruturais e pela maior concentração de unidades de terraços altos, implica relativa canalização dos fluxos de extravasamento e tende a produzir inundações com maiores profundidades e elevadas velocidades em comparação ao setor de jusante.

Devido à abertura lateral do vale, no trecho de jusante há tendência de intensificação da componente lateral dos extravasamentos. As inundações ocorrem primeiramente nas concavidades das planícies que correspondem às margens convexas, paleomeandros e backswamps, onde podem ocorrer transporte e deposição por mecanismos de tração. Gradualmente, a inundação espraia-se ao nível principal da planície, implicando redução de sua profundidade e dissipação da energia cinética devido à mudança no vetor direção e aumento da rugosidade. Esta necessidade de dissipação da energia do fluxo de inundações do rio Ribeira de Iguape reflete, no trecho de montante entre Eldorado e Sete Barras, na ocorrência de backflooding, com a inundação de planícies de tributários a partir de entradas de cunhas de direção geral jusante-montante. Estes processos de inundação dos afluentes do Ribeira de Iguape no trecho estudado foram previamente interpretados 
durante a fotointerpretação morfológica e ratificados ao longo do mapeamento geomorfológico, particularmente durante as campanhas de campo em que depoimentos de moradores relataram a ocorrência de tais cunhas de inundação durante os eventos de 1997 e 2011.

A diminuição da velocidade decorre na sedimentação de amplos pacotes em suspensão de areias finas, silte e argila. Estas tendências hidrodinâmicas exemplificam a funcionalidade de atenuação das inundações por efeito da diminuição das velocidades e estocagem temporária dos fluxos excedentes.

O fluxo efetivo do transbordamento em planícies fluviais meândricas ocorrem próximo ao canal em barras, ilhas e cordões arenosos, e podem ainda ocupar formas deprimidas na planície como meandros abandonados. Nestes casos, além da maior proporção de frações granulométricas arenosas, observa-se um maior número de descontinuidade texturais do material e uma estrutura sedimentar que tende a ser laminar a ligeiramente ondulada, e não homogênea, como são os pacotes de retaguardas das planícies. Nestes últimos, a lêntica deposição resulta na composição de textura argilo-siltosa mais homogênea, que se relacionam à eficiência do processo de dissipação de energia que as planícies de inundação realizam ao amortecer o fluxo remontante que extravasa do canal principal

As suscetibilidades à inundação, portanto, podem ser distintas e sua compreensão passa necessariamente pelas relações de magnitude-frequência estabelecidas em distintas seções transversais ao longo do vale e pela conectividade hidráulica interna à planície e em relação aos tributários.
Do ponto de vista morfogenético, o mapa geomorfológico evidenciou a atuação tectônica expressa pelas mudanças do índice de sinuosidade, acompanhadas pela alteração do padrão de forma das seções transversais, concentração de barras arenosas e ilhas, e pela diferença de concentração de unidades de terraços baixos.

Estas mudanças nos padrões de distribuições de formas podem ocorrer devido ao desenvolvimento e formato do Graben de Sete Barras simultâneo ao seu basculamento (MELO, 1990). A ascensão relativa do bloco de sudoeste deste Alinhamento de Guapiara é sugerida pela presença de remanescentes de níveis de terraços pleistocênicos que estão ausentes à NE do alinhamento. Associado a esta ascensão relativa, sugere-se um duplo processo que permitiu a manutenção de formas: basculamento positivo da porção SW (no trecho de montante) em relação à $\mathrm{NE}$, deixando a primeira altimetricamente superior à segunda; e, a exumação de diques máficos, que podem contribuir para a sustentação dos níveis de terraços altos nesta porção em relação às localizadas à jusante. $\mathrm{O}$ ganho altimétrico relativo do trecho de montante e a presença de estruturas de diques aflorantes pontualmente ao longo do trecho podem explicar a diferenciação entre os trechos de montante e jusante.

As diferenças nos padrões do canal meandrante e nos índices de sinuosidade muito distintos quando se compara os setores de montante e jusante da área estudada sugerem que, na primeira, ocorram meandros irregulares controlados parcialmente pela estrutura, enquanto na segunda ocorrem meandros caracteristicamente senoidais e amplos (Figura 15).
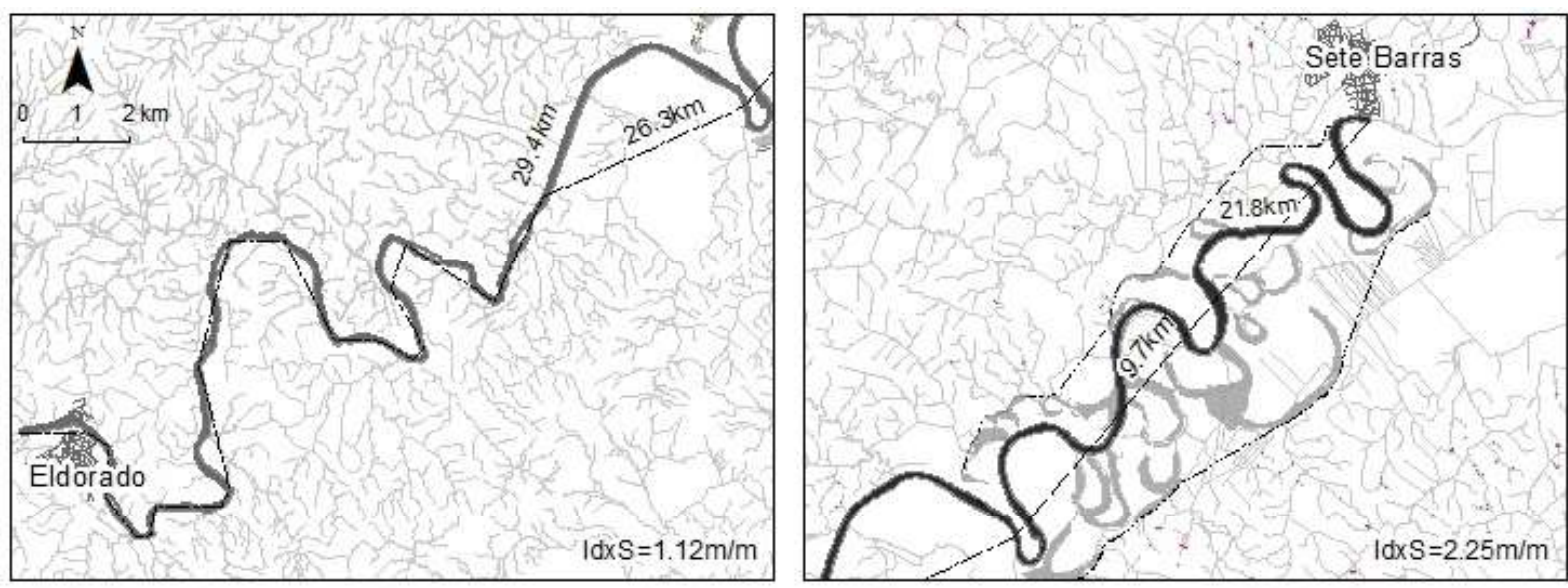

Figura 15 - Canal principal do trecho montante e jusante e respectivos Índices de Sinuosidade. 
À montante, os diâmetros dos meandros são menores e há presença de trechos de canais retilíneos interferindo na regularidade do padrão fluvial e da largura do cinturão de meandramento. As barras laterais são raras à montante e, quando ocorrem, são curtas e estreitas. Em geral as margens neste setor são elevadas formando barrancas de até $5 \mathrm{~m}$ de altura. $\mathrm{O}$ controle sobre a drenagem é observado também na restrição da largura do fundo de vale e sucessões de alteração do eixo principal do vale, os quais delimitam o meandramento e a migração lateral do canal. Além disso, a concentração de barras centrais no trecho de montante é indicador da presença de afloramentos rochosos no leito que favorecem a sedimentação e a formação inclusive de ilhas fluviais. À jusante, os meandros mais largos e sucessivos, em cinturão meândrico que, em alguns trechos, tangencia a base da vertente no lado direito do vale, são indicadores de que não há fortes condicionantes estruturais, excetuando-se a manutenção da direção do eixo da drenagem SW-NE.

No trecho montante há maior número de compartimentos de terraços altos e baixos, dispostos em diferentes faixas de altitude. Isto revela intensa dinâmica erosiva fluvial do canal principal, o que pode denotar em sucessivas retomadas de processos de incisão dos canais possivelmente ao longo do Holoceno, dada a incisão em baixos terraços de conteúdo pelítico, possivelmente elaborados em ambiente fluvial meândrico tropical.

À jusante, essa incisão fluvial significativa não é percebida. A abertura lateral do vale, juntamente com condições paleoclimáticas favoráveis, promoveu a instalação de sistema meândrico típico, com agradação por migração lateral do canal combinada a processos de inundação. $\mathrm{O}$ abatimento do bloco à jusante em relação ao bloco de montante pode ter favorecido a erosão dos Terraços altos plio-pleistocênicos ao longo da transição para climas mais úmidos no início do Holoceno.

Alguns remanescentes de terraços altos à montante são simétricos em ambos os flancos do vale assinalando alteração da mudança do nível de base significativa neste trecho, configurando um indicativo de modificação em virtude de fatores estruturais. Em contraposição, no setor de jusante exemplares de terraços encontram-se isolados na retaguarda da planície e dispostos de maneira assimétrica ocorrendo em apenas um dos lados do vale, sugerindo abandono gradativo da superfície de acumulação, o que pode ter sido decorrente de uma mudança das condições hidrodinâmicas de erosão e sedimentação.

\section{Conclusões}

Os níveis da abordagem geomorfológica apoiados na cartografia geomorfológica esclareceram a distribuição das formas e dos materiais, viabilizando apontamentos sobre tendências espaciais hidromorfodinâmicas atuais e pretéritas, particularmente relacionadas a fluxos fluviais extremos, permitindo inferir níveis de suscetibilidades à inundação por compartimento geomorfológico ao longo do setor ESB.

A planície fluvial do baixo rio Ribeira de Iguape (setor ESB) possui diversidade de formas fluviais de canal, planície e terraço. As formas de canal assinalaram o controle estrutural sobre a drenagem da região, o eixo de desenvolvimento do vale e o padrão de meandramento, apontados, entre outros fatores, pelo índice de sinuosidade. A planície fluvial compõe-se, basicamente, de dois níveis topograficamente distintos (1 e 2), que abrangem a maior parte da área estudada $(>70 \%)$ com inúmeras irregularidades e descontinuidades morfológicas. Além dos níveis principais, as planícies são compostas por paleocanais, cordões marginais e diques fluviais, além de backswamps, cujas distribuições ratificam os subtipos meândricos estabelecidos: um, à montante, mais controlado pela estrutura, e outro à jusante, menos fortemente controlado. Os terraços abrangeram dois níveis de terraços baixos (distintos em topografia e sedimentologia) e terraços altos sustentados pela Formação Eldorado.

Esta variabilidade de formas fluviais exprime-se na sucessão de patamares altimétricos e na diversidade de rugosidade da superfície, as quais sugerem que as relações cota-vazão sejam distintas em cada seção transversal ao longo do perfil longitudinal do canal.

Tal constatação implica que setores de planície de inundação em distintos pontos do perfil longitudinal apresentam diferentes níveis de suscetibilidades. Logo, a compreensão da suscetibilidade às inundações, além de passar pelas características topográficas e de proximidade com canal atual, deve agregar outros aspectos relativos à heterogeneidade geomorfológica e à variabilidade dos fluxos na planície. Estes são indicados, por exemplo, pelas formas erosivas e por outras marcas que denotam a efetividade, potência e regime do fluxo fluvial, capazes de oferecer pistas sobre a conectividade dos compartimentos fluviais em eventos de maiores magnitudes. 


\section{Agradecimentos}

À Capes pelo financiamento da bolsa de estudos de doutorado de Yuri Veneziani. Aos revisores anônimos pelas contribuições. AAndré Barreiros e Marcos Roberto Pinheiro pelo apoio no levantamento dos materiais e descrição pedossedimentológica em campo.

\section{Referências Bibliográficas}

AB'SABER, A. N. Uma revisão do quaternário paulista: do presente para o passado. Revista Brasileira de Geografia, v. 31, n. 4, p. 1-47, 1969.

AB'SABER, A. N. Participação da Depressão e Superfícies Aplainadas na Compartimentação do Planalto Brasileiro. Geomorfologia, v. 28, 1972.

ALCÁNTARA-AYALA, I. Geomorphology, natural hazards, vulnerability and prevention of natural disasters in developing countries. Geomorphology, v. 47, p. 107-124, 2002.

ALLEN, J. R. L. A review of the origin and characteristics of recent alluvial sediments. Sedimentology, v. 5, p. 89-191, 1965.

ALLEN, J. R. L. On Bed Forms and Palaeocurrents. Sedimentology, v. 6, n. 3, p. 153-190, 1966.

ALMEIDA, F. F. M. D. Fundamentos Geológicos do Relêvo Paulista. Teses e Monografia, v. 14, p. 5 - 90, 1974.

AMARAL, W. I. Arquitetura em tempo - Estudo das áreas inundáveis urbanizadas de Eldorado-SP. 2014. 87 (Master). Instituto de Geociências, Universidade de São Paulo, São Paulo.

BENITO, G.; THORNDYCRAFT, V. R. Systematic, Palaeoflood and Historical Data for the Improvement of Flood Risk Estimation: Methodological Guidelines. Madrid: CSIC - Centro de Ciencias Medioambientales, 2004. 117 ISBN 84-921958-3-5.

BERTUCCI, T. et al. Late Holocene palaeotemperatures and palaeoenvironments in the Southeastern Brazilian coast inferred from otolith geochemistry. Palaeogeography, Palaeoclimatology, Palaeoecology, v. 503, p. 40-50, 2018.

BIGARELLA, J. J. Estrutura e origem das paisagens tropicais e subtropicais. Florianópolis: Ed. da UFSC, 2007.

BIGARELlA, J. J.; ANDRADE, G. D. Contribution to the study of the Brazilian Quaternary. International studies in the Quaternary., v. Special Paper, p. 443-451, 1965.

BIGARELlA, J. J.; MOUSINHO, M. R. Contribuições ao estudo da Formação Pariquera-Açu. Boletim Paranaense de
Geografia, v. 16 e 17, p. 17 a 41, 1965a.

Pediplanos, pedimentos e seus depósitos correlativos no Brasil. Boletim Paranaense de Geografia, v. 16 e 17, p. 117 a 151, 1965b.

BRIDGE, J. S. Rivers and floodplain: forms, processes, and sedimentary record. Oxford: Blackwell Science Ltd., 2003. 491 ISBN 978-0-632-6489-2.

BRUNSDEN, D. Geomorphological events and ladform change. Zeitschrift für Geomorphologie, v. 40, n. 3, p. 273 -288, 1996.

CENAD. Anuário brasileiro de desastres naturais: 2013. NACIONAL, M. D. I.;CIVIL, S. N. D. P. E. D., et al. Brasília: Ministério da Integração Nacional: 105 p. 2014.

CEPAGRI. Clima dos municípios paulistas: a classificação climática de Koeppen para o Estado de São Paulo. Campinas, p. CEPAGRI Meteorologia Unicamp. Centro de Pesquisas Meteorológicas e Climáticas Aplicadas a Agricultura., 2015. Disponível em: < https://orion.cpa.unicamp.br/outrasinformacoes/clima-dos-municipios-paulistas.html $>$. Acesso em: 03/21/2018.

CHOW, V. T. Open Channel Hydraulics. New York, St Louis, San Francisco, Tokyo, Toronto, etc.: McGraw-Hill Book Company, INC.

Kogakusha Company, LTD, 1959. 350

CHRISTOFOLETTI, A. Geomorfologia Fluvial: Volume 1. São Paulo: Ed. Edgar Blücher, 1981.

COLTRINARI, L. Cartografia geomorfológica detalhada: a representação gráfica do relevo entre 1950-1970. Revista Brasileira de Geomorfologia, v. 12, n. 3, p. 121 a 130, 2011. CPRM. Mapa Geológico 1:100.000, Folha SG-22-X-BVI, Eldorado Paulista. 1. Rio de Janeiro: CPRM - Serviço Geológico do Brasil 2013.

Mapa Geológico 1:100.000, Folha SG-23-V-A-I, Registro. 1. Rio de Janeiro: CPRM - Serviço Geológico do Brasil 2014.

. GEOBANK - Banco de dados geoespaciais da CPRM. Rio de Janeiro, p. CPRM - Serviço Geológico do Brasil, 2016. Disponível em: < http://geobank.cprm.gov.br/ >. Acesso em: $01 / 05$.

CRED; GUHA-SAPIR, D. EM-DAT - The International Disaster Database., Brussels, p. EM-DAT provides an objective basis for vulnerability assessment and rational decision-making in disaster situations. For example, it helps policymakers identify the disaster types that are most common in a given country and that 
have had significant historical impacts on human populations., 2018. Disponível em: < https://www.emdat.be $>$. Acesso em: 07/17/2018.

CRICKMAY, C. H. The work of the River. London: The Macmillan Press LTD, 1974. 270 ISBN 333-17840-8.

DAEE. Ribeira do Iguape. Águas e Energia Elétrica. São Paulo: DAEE - Departamento de Águas e Energia Elétrica: 55-66 p. 1999.

DEMEK, J. Manual of detailed geomorphological mapping. Prague: Czechoslovak Academio Sciences, IGU, 1972. 200

EMPLASA. Projeto Mapeia São Paulo: Fotografias aéreas e ortofotos. EMPLASA - EMPRESA PAULISTA DE PLANEJAMENTO METROPOLITANO S/A. São Paulo: Emplasa - Sistema de Compartilhamento de Dados 2010/2011.

ERSKINE, W. Alluvial cutoffs as indicators of former channel conditions. Earth Surface Processes and Landforms, v. 17, p. 23-37, 1992.

FF. Plano de Manejo da Área de Proteção Ambiental Várzeas do Rio Tietê. FLORESTAL, F.-F.;AMBIENTE, S. D. E. D. M., et al. São Paulo: Fundação Florestal. 3: 17-20 p. 2013.

GUSTAVSSON, M.; KOLSTRUP, E.; SEIJMONSBERGEN, A. C. A new symbol-and-GIS based detailed geomorphological mapping system: Renewal of a scientific discipline for understanding landscape development. Geomorphology, v. 77, n. 1-2, p. 90-111, 2006.

HART, M. G. Geomorphology: Pure and Applied. London: George Allen \& Unwin, 1986. 226

HOOKE, J. M. River channel adjustment to meander cutoffs on the River Bollin and River Dane, northwest England. Geomorphology, v. 14, p. 235-253, 1995.

IGC. Modelo Digital de Terreno (MDT) hidroforçado para o Estado de São Paulo, resolução reamostrada $1 \mathrm{~m}$. IGC- INSTITUTO GEOGRÁFICO E CARTOGRÁFICO DO ESTADO DE SÃO PAULO. São Paulo: IGC 2010/2011.

Bases cartográficas oficiais digitais. IGC INSTITUTO GEOGRÁFICO E CARTOGRÁFICO DO ESTADO DE SÃO PAULO. São Paulo: IGC 2015.

IPT. Mapa Geomorfológico do Estado de São Paulo. SÉRIE MONOGRAFIAS, V., 2. São Paulo: IPT - Instituto de Pesquisas Tecnológicas do Estado de São Paulo 1981.

KNIGHTON, A. D. Fluvial forms and process: a new perspective. London: Arnold, 1998. 383
LEOPOLD, L. B.; WOLMAN, M. G. River channel patterns - braided, meandering, and straight. U.S. Geological Survey. Washington, D.C., p.39-85. 1957

LEOPOLD, L. B.; WOLMAN, M. G. River Meanders. Geological Society of America Bulletin, v. 71, n. 6, p. 769, 1960.

LEOPOLD, L. B.; WOLMAN, M. G.; MILLER, J. P. Fluvial Processes in Geomorphology. San Francisco: W. H. Freeman \& Co., 1964. 531 ISBN 9780486685885.

LUZ, R. A. D.; RODRIGUES, C. Anthropogenic changes in urbanised hydromorphological systems in a humid tropical environmen: RIver Pinheiros, São Paulo, Brazil. Zeitschrift für Geomorphologie, v. 59, p. 109-135, 2015.

MELO, M. S. D. Formacao Pariquera-Açu e depositos relacionados: sedimentaçao, tectonica e geomorfogênese. 1990. (Master). Instituto de Geociências, Universidade de São Paulo, São Paulo.

MELO, M. S. D.; FERNANDES, L. A.; COIMBRA, A. M. Evolução tectono-sedimentar Cenozóica do Baixo Vale do Rio Ribeira do Iguape, SP., XXXVI Congresso Brasileiro de Geologia, 1990. Natal (RN). SBG - Sociedade Brasileira de Geociências. p.2250-2255.

MELO, M. S. D. et al. Formação Sete Barras - Unidade sedimentar pré-Pariquera-Açu no Vale do Ribeira do Iguape, SP., Simpósio de Geologia do Sudeste, 1989. Rio de Janeiro (RJ). SBG - Sociedade Brasileira de Geologia. p.107-108.

MELO, M. S. D. et al. O graben (Terciário?) de Sete Barras, Vale do Ribeira do Iguape, SP. Revista Brasileira de Geociências, v. 19, n. 1, p. 260-262, 1989.

MIALL, A. D. Fluvial Sedimentology. Calgary: Canadian Society of Petroleum Geologists, 1978. 859 ISBN 0-92023003-2.

MIRANDA, E. E. D. C. Brasil em Relevo. Campinas, 2008. Disponível em: < http://www.relevobr.cnpm.embrapa.br $>$.

MORISAWA, M. Rivers Form and Process. New York: Longman, 1985. 222 ISBN 0-582-48982-2.

PANAPANÁ. Plano da Bacia Hidrográfica Ribeira de Iguape e Litoral Sul. PANAPANÁ Informação e Educação

CBH-RB/Governo do Estado de São Paulo/Fehidro/Fundag. Registro, p.436. 2016

RICCOMINI, C. O Rift Continental do Sudeste do Brasil. 1989. 256 (PhD). Departamento de Geologia Sedimentar, Universidade de São Paulo, São Paulo. 
RODRIGUES, C. Geomorfologia Aplicada: Avaliação de experiências e de instrumentos de planejamento físicoterritorial e ambiental brasileiros. 1997. (PhD). Departamento de Geografia, Universidade de São Paulo, São Paulo.

. X Encontro Nacional da Anpege. Diversidade da geografia brasileira: escalas e dimensões da análise e da ação, 2015. Presidente Prudente. Anpege.

ROSS, J. L. S. A Morfogênese da bacia do Ribeira do Iguape e os sistemas ambientais. GEOUSP, n. 12, p. 21-46, 2002.

ROSS, J. L. S.; MOROZ, I. C. Mapa Geomorfológico do estado de São Paulo, 1:500.000. 1. São Paulo: Laboratório de Geomorfologia, Departamento de Geografia, FFLCHUSP/IPT/ FAPESP: Vols. I e II p. 1997.

SANTANA, C. L. Geomorfologia da Planície Fluvial do Rio Ribeira de Iguape entre Sete Barras e Eldorado (SP): Subsídios ao planejamento físico-territorial de áreas inundáveis. 2008. 282 (Metrado). Faculdade de Filosofia, Letras e Ciências Humanas, Departamento de Geografia., Universidade de São Paulo, São Paulo.

SANTOS, R. D. D. et al. Manual de descrição e coleta de solos no campo. Viçosa: SBCS - Sociedade Brasileira de Ciência de Solo

Embrapa - Centro Nacional de Pesquisa de Solos, 2005.

SEADE. IMP - Informações dos Municípios Paulistas. São Paulo, p. Informações dos Municípios Paulistas Séries históricas, reunidas em diversos temas, que podem ser pesquisadas por municípios, regiões do Estado de São Paulo e distritos da capital, 2013.
Disponível em: < http://www.imp.seade.gov.br/frontend/\#/ >

SIGRB. Sistema de Informações Geográficas do Ribeira de Iguape e Litoral Sul. Registro, p. Reune informações necessárias para a administração dos Recursos Hídricos da Bacia URGHI 11, as quais também são úteis para a Gestão Territorial e Ambiental., 2017. Disponível em: < http://www.sigrb.com.br/ >.

TARIFA, J. R. Unidades climáticas dos maciços litorâneos da Juréia-Itatins. In: MARQUES, O. A. V. e DULEBA, W. (Ed.). Estação Ecológica Juréia-Itatins: Ambiente Fìsico, Flora e Fauna. São Paulo: Holos, 2004. p.42-50.

THEOdorovicz, A.; THEOdorovicz, A. M. G. Atlas geoambiental: subsídios ao planejamento territorial e à gestão ambiental da bacia hidrográfica do rio Ribeira do Iguape. São Paulo: CPRM, 2007. 91

TOONEN, W. H. J. A holocene flood record of the Lower Rhine. 2013. 205 (PhD). Faculty of Geosciences, Utrecht University, Utrecht.

TRICART, J. Principes et méthodes de la Géomorphologie. Paris: Masson, 1965. 201

VEYRET, Y. Os riscos: o homem como agressor e vítima do meio ambiente. São Paulo: Contexto, 2015. 316 ISBN 97885-7244-345-8.

WOHL, E. Spatial heterogeneity as a component of river geomorphic complexity. Progress in Physical Geography, v. 40, n. 4, p. 598-615, 2016.

Connectivity in rivers. Progress in Physical

Geography, v. 41, n. 3, p. 345-362, 2017. 